\title{
ARCHAEOLOGY OF DESTRUCTION: TOPRAKKALE
}

\author{
By BÜLENT GENÇ
}

Toprakkale is the site that constitutes the starting point for the archaeology of Urartu, but the history of the largely destructive early excavations of the site is shrouded in darkness. The presence of items on the antiquities market said to come from the Van region attracted the interest of Austen Henry Layard, which led to brief excavations at the site of Toprakkale by the British Museum under Hormuzd Rassam in 1877, followed by further also brief investigations by K. Kamsarakan as well as continued illegal excavations. It is commonly held that Carl Friedrich Lehmann-Haupt and Waldemar Belck excavated here between 18981899, but research performed in the Ottoman Archives of the Prime Minister's Office reveals their claim to have excavated there to be fraudulent and empty. This article uses primary source material from Ottoman archives to investigate the excavation history of one of the most iconic sites for the beginnings of Urartian Studies, and compels us to re-evaluate what we think we know about Toprakkale and the provenance of the objects associated with it.

Toprakkale/Rusahinili Qilbanikai is located roughly $5 \mathrm{~km}$ east of the Van Citadel (Tušpa), the Urartian capital. The limestone natural hill on which the citadel stands is connected to Mount Zimzim behind it (Fig. 1). The citadel is 400 metres long on the north-south axis and 60-70 metres wide. The Urartian name of Toprakkale (Rusahinili Qilbanikai) is accepted to have derived from a tablet dating to the reign of Rusa (II?), son of Argišti (Lehmann-Haupt 1906: 105, Fig. 77a-b); however, there is an ongoing debate on whether the citadel was built by Rusa son of Argišti, or Rusa son of Erimena. ${ }^{1}$

Toprakkale is a significant site as it is the location of the first archaeological excavations concerning Urartu. Within a century, it is supposed to have been excavated by Dr. Reynolds, Captain Emilius Clayton, Hormuzd Rassam, Carl Ferdinand Friedrich Lehmann-Haupt and Waldemar Belck, Iosif Abgarovich Orbeli and lastly by Afif Erzen. What attracted so many researchers to this site? What is the true relationship between the artefacts that were believed to originate from Toprakkale -and thereby attracted excavators - and the site itself? In this article, by using various documents from the Ottoman Archives, I will explore the Toprakkale excavations from the 1870s onwards, via a re-assessment of the early researchers who worked there and the various excavation periods, and through discussion of the confusion caused by artefacts reported to have originated in Toprakkale ${ }^{2}$ (Tables 1-2).

\section{Toprakkale's Rise to Prominence: the Finds and First Excavations}

Austen Henry Layard and Hormuzd Rassam. In a book published in 1874 Garegin V. Srvandztyants mentions finds discovered above Toprakkale, in an area he calls the Zimzim cave, including stones, large pithoi, small pottery, copper (bronze?) chair fragments and a bronze figurine depicting a man sitting on a ram. Srvandztyants states that this bronze statue was taken to Constantinople (Istanbul) by the bishop of Edessa (Srvandztyants 1874: 132-133). ${ }^{3}$ Furthermore, in 1877 various bronze artefacts and objects said to have come from Toprakkale began to be sold on the international market. It is widely thought that these artefacts stimulated the interest of Austen Henry Layard, who was employed at the British Embassy in Istanbul at the time (Barnett

\footnotetext{
${ }^{1}$ Salvini dates the citadel to Rusa, son of Argišti based on written documents found in Toprakkale (Salvini 2006: 117), while Seidl dates it to Rusa, son of Erimena (Seidl 2012: 178). For discussions on Rusa, son of Erimena, see Fuchs 2012: 135-161; Kroll 2012: 183-186; Roaf 2012: 187-216; Hellwag 2012: 227-241; Salvini 2012: 128-133.
}

\footnotetext{
${ }^{2}$ I would like to thank Dr. Vural Genç for the transcription of these documents.

${ }^{3}$ I would like to thank Dr. Yervand Grekyan, who kindly shared relevant information in Srvandztyants' book and translated it from the Armenian language.
} 
TABle 1 The Correspondence about Austen Henry Layard and Hormuzd Rassam

Austen Henry Layard and Hormuzd Rassam

\begin{tabular}{|c|c|}
\hline Date of Documents & Archive Numbers \\
\hline August 6,1860 & HR. MKT. 362/50, 18 Muharrem 1277 \\
\hline August 6,1860 & HR. MKT. 344/44, 18 Muharrem 1277 \\
\hline March 1877 & MF. MKT. 46/113, Mart 1293 \\
\hline September 15, 1877 & İ. DH. 756/61682, 7 Ramazan 1294 \\
\hline November 22, 1877 & MF. MKT. 51/180, 16 Zilkade 1294 \\
\hline December 27, 1877 & MF. MKT. 52/75, 21 Zilhicce 1294 \\
\hline December 30, 1877 & MF. MKT. 52/75, 21 Zilhicce 1294 \\
\hline February 14,1878 & MF. MKT. 55/11, 2 Şubat 1293 \\
\hline April 20, 1878 & MF. MKT. 55/62, 17 Rabiulahir 1295 \\
\hline April 20, 1878 & MF. MKT. 55/62, 8 Nisan 1294 \\
\hline April 20, 1878 & MF. MKT. 55/87, 17 Rabiulahir 1295 \\
\hline April 20, 1878 & MF. MKT. 55/104, 17 Rabiulahir 1295 \\
\hline April 30,1878 & MF. MKT. 55/141, 27 Rabiulahir 1295 \\
\hline May 11,1878 & MF. MKT. 56/49, 9 Cemazeyilevvel 1295 \\
\hline June 18,1878 & MF. MKT. 57/61, 6 Haziran 1294 \\
\hline August 17,1878 & MF. MKT. 57/155, 18 Şaban 1295 \\
\hline October 3,1878 & MF. MKT. 58/43, 6 Şevval 1295 \\
\hline October 17,1878 & MF. MKT. 58/51, 20 Şevval 1295 \\
\hline December 3,1878 & HR. TO. 261/40, 8 Zilhicce 1295 \\
\hline March 9, 1879 & MF. MKT. 60/102, 15 Rabiulevvel 1296 \\
\hline August 3,1879 & MF. MKT. 64/37, 14 Şaban 1296 \\
\hline May 6, 1882 & MF. MKT. 75/142, 24 Nisan 1298 \\
\hline March 13, 1883 & MF. MKT. 79/79, 4 Cemazeyilevvel 1300 \\
\hline Mach 25, 1884 & Y. PRK. EŞA. 4/14, 27 Cemazeyilevvel 1301 \\
\hline January 28,1886 & MF. MKT. 89/89, 16 Kânunusani 1301 \\
\hline November 12,1888 & MF. MKT. 103/42, 8 Rabiulevvel 1306 \\
\hline January 30,1894 & MF. MKT. 201/14, 22 Receb 1311 \\
\hline
\end{tabular}

1950: 3-5; Barnett 1954: 16-19; Piotrovsky 1969: 17). Layard writes in a letter dated August $3^{\text {rd }}, 1877$ to Dr Birch that a man brought him Assyrian bronze artefacts found in the vicinity of Van, which he remarks appear to be fragments of a throne or a chest - one where a figure's arms are folded on his chest with lion claws. He compares artefacts found in Nimrud. He claims that the bronze or copper panel fragments and lion claws are reminiscent of the throne fragments discovered in Nineveh. He also mentions that some of the panel fragments contain Assyrian texts (Barnett 1950: 3-5). It is highly likely that the group of finds Layard purchased in Istanbul and those Srvandztyants mentions are comparable. On visiting Toprakkale Rassam refers to an artificial hill much like those of the Assyrians (Rassam 1897: 130). Rassam had asked both the Pasha of the province and Layard himself for permission to dig it, but was refused. Also Barnett notes that in Rassam's book (Rassam 1897), "the all-important point, the reference to the source of the bronzes, is there discreetly omitted" (Barnett 1950: 5). It appears that the reason why Toprakkale was perceived to be an Assyrian settlement, and its subsequent excavation as such, is due to Austen Henry Layard and Hormuzd Rassam's excavations in Mesopotamia.

It is often mentioned that Layard sent Rassam, with whom he had collaborated in his Assyrian excavations, to Van to investigate the place where the items he purchased came from (Barnett 1950: 3-5; Piotrovsky 1969: 17). ${ }^{4}$ Rassam went to Toprakkale in 1877 with a stopover in Van

\footnotetext{
${ }^{4}$ It must be noted that Layard came to Van in 1849 , long before 1877 when he was attracted to the aforementioned bronze objects, and drew the plans of Argišti I's tomb and its main hall (Layard 1853: 389-410). Layard also briefly excavated the Treasure Gate/Analıkız on the northeastern slope of the Van Citadel, based on an excavation permit
}

that allowed the sharing of finds, in accordance with the regulations of the Ottoman Empire at the time (Layard 1853: 398-399). It would be pertinent to accept that this excavation, about which there is not much detail, is the first in Urartian archaeology. 
TABle 2 The Correspondence about Carl Ferdinand Friedrich Lehmann-Haupt and Waldemar Belck

Carl Ferdinand Friedrich Lehmann-Haupt and Waldemar Belck

\begin{tabular}{|c|c|}
\hline Date of Documents & Archive Numbers \\
\hline April 7, 1898 & İ.HR. 358/45, 16 Zilhicce 1315 \\
\hline April 13, 1898 & İ.HR. 358/45, 16 Zilhicce 1315 \\
\hline May 8, 1898 & İ.HR. 358/45, 16 Zilhicce 1315 \\
\hline May 9, 1898 & BEO.1122/84128, 20 Zilhicce 1315 \\
\hline May 13, 1898 & İ.HR. 358/45, 16 Zilhicce 1315 \\
\hline May 23, 1898 & MF. MKT. 397/1, 2 Muharrem 1316 \\
\hline May 26, 1898 & MF. MKT. 397/1, 5 Muharrem 1316 \\
\hline June 11,1898 & BEO. 1142/85587, 24 Muharrem 1316 \\
\hline June 12,1898 & BEO. 1142/85587, 24 Muharrem 1316 \\
\hline July 2, 1898 & BEO. 1152/86381, 16 Safer 1316 \\
\hline July 6,1898 & BEO. 1152/86381, 16 Safer 1316 \\
\hline August 2,1898 & BEO. 1171/87788, 18 Rabiulevvel 1316 \\
\hline August 4,1898 & BEO. 1152/86381, 16 Safer 1316 \\
\hline October 23,1898 & DH. MKT. 2122/17, 7 Cemazeyilahir 1316 \\
\hline November 3,1898 & BEO. 1206/90387, 18 Cemazeyilahir 1316 \\
\hline November 15,1898 & DH. MKT. 2134/71, 1 Receb 1316 \\
\hline November 30, 1898 & DH. ŞFR. 229/63, 18 Teşrinisani 1314 \\
\hline November 30, 1898 & DH. MKT. 2143/16, 19 Receb 1316 \\
\hline December 3, 1898 & DH. MKT. 2143/16, 19 Receb 1316 \\
\hline May 2, 1899 & MF. MKT. 447/47, 25 Zilhicce 1316 \\
\hline May 2, 1899 & MF. MKT. 447/47, 25 Zilhicce 1316 \\
\hline May 4, 1899 & DH. MKT. 2197/1, 23 Zilhicce 1316 \\
\hline May 6, 1899 & MF. MKT. 447/47, 25 Zilhicce 1316 \\
\hline June 5,1899 & Y. PRK. UM. 46/54, 25 Muharrem 1317 \\
\hline July 4, 1899 & MF. MKT. 447/47, 25 Zilhicce 1316 \\
\hline September 2, 1899 & DH. MKT. 2242/130, 28 Rabiulahir 1317 \\
\hline September 2, 1899 & DH. MKT. 2197/1, 29 Zilhicce 1316 \\
\hline September 4, 1899 & DH. MKT. 2242/130, 28 Rabiulevvel 1317 \\
\hline September 5, 1899 & DH. MKT. 2242/130, 28 Rabiulevvel 1317 \\
\hline November 16,1899 & BEO. 1402/105134, 12 Receb 1317 \\
\hline February 11, 1900 & DH. MKT. 2304/27, 11 Şevval 1317 \\
\hline February 14, 1900 & DH. MKT. 2242/130, 28 Rabiulahir 1317 \\
\hline May 22,1900 & BEO. 1489/111666, 22 Muharrem 1318 \\
\hline
\end{tabular}

(Rassam 1897: 111, 130). He explored Assur (Qalat Šergat), Kalhu (Nimrud) and Balawat (ImgurEnlil) in 1878-79 and could not return to Van.

In 1879 Captain Emilius Clayton and Dr Reynolds are said to have carried out excavations in Toprakkale on behalf of the British Museum and Rassam is supposed to have continued these in subsequent years (Lehmann-Haupt 1931: 455). Clayton ended his work in Toprakkale after a smallscale excavation during which he found only a few iron spear and arrowheads (Barnett 1950: 19). In 1880 the American missionary Dr Reynolds and the British Vice-consul in Van, Clayton, hastily excavated Toprakkale under the supervision of Rassam ${ }^{5}$ on behalf of the British Museum (Barnett 1972: 163). Clayton's letter to Layard, dated May $11^{\text {th }}, 1880$, serves as the first excavation report and site plan of Toprakkale (Barnett 1950: 9-12, Fig. 5; Zimansky 2011: 59-60) (Fig. 1) and is noteworthy in terms of understanding the time of the excavation, locations of finds, and related architectural remains. Clayton says that the excavation in Toprakkale began on March $3^{\text {rd }}, 1880$, in an area he refers to as $\mathrm{A}$ - he divides the citadel into two parts (A on the north and $\mathrm{B}$ on the south). We understand that he excavated a temple from "the most perfectly hewn blocks of a sort of trap rock of a

\footnotetext{
${ }^{5}$ Rassam's excavations in $1878-1882$ were very significant, however, it is said that he was mostly absent and left it to several trusted men to run the dig (Reade 1993: 56-57).
} 


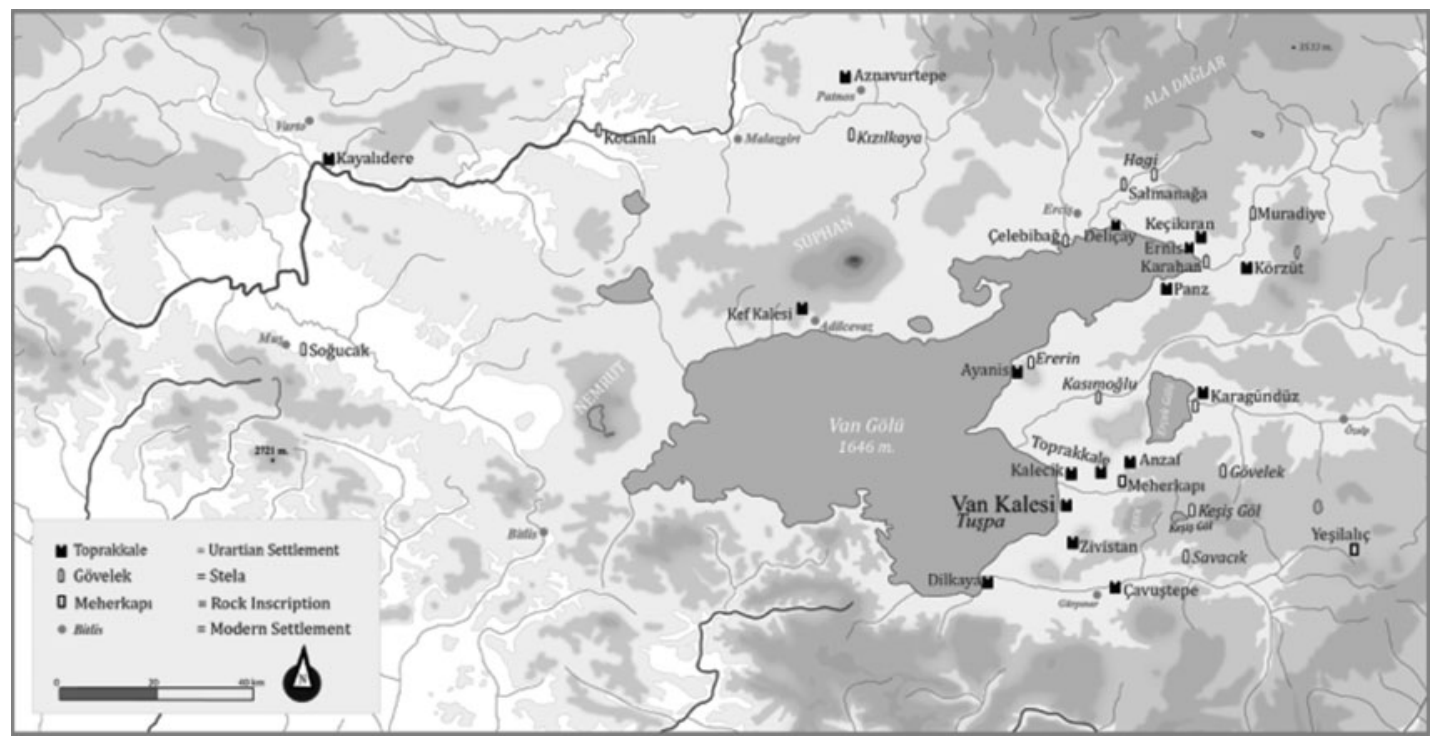

Fig. 1 Tušpa, the capital of Urartu and Toprakkale (A. Tan)

dark grey colour", his plan drawing, and subsequent excavations. In area B, he refers to rough-cut stone walls as well as ivory and bronze artefacts (Barnett 1950: 9-12, Fig. 5).

Rassam left the responsibility of this excavation to inexperienced people and busied himself with his excavations in Nimrud, Kuyunjik, Balawat, and Assur. However, once the temple was discovered he returned to Van on July $29^{\text {th }}, 1880$ and carried out a short-term excavation in Toprakkale (Rassam 1897: 378; Barnett 1950: 8, 17).

We understand from Rassam's own words that after the first destruction by Clayton, the second destruction of Toprakkale took place by his initiative. He divided the hill into three and dug tunnels from one end to the other looking for building remains: he perceived mud-brick architecture as rubble and earth, considering only the stone foundations worthy of keeping. The foundation of the temple and the three mosaic-floored rooms discovered on the southern slopes of the hill are worth noting. Other than various finds, the altar in front of the temple, seen in the only photograph of Toprakkale published by Rassam (Fig. 3), was later handed over to the Imperial Museum (Müze-i Hümayun) in Istanbul by Lehmann-Haupt. ${ }^{6}$ Rassam refers to a plan when discussing the temple foundation as well as several other details but there is no information about this plan (Rassam 1897: 378). However, his plan of the Haldi temple was found subsequently in the British Museum with several other records in 1951 (Barnett 1954: 3, Fig. 1). ${ }^{7}$ The many deficiencies and errors of this very debatable and destructive excavation left aside, scholars have emphasised that it made the first serious contribution to Urartian archaeology (Barnett 1982: 316-317). Nonetheless, it is more pertinent to argue that rather than a significant contribution, Toprakkale created ambiguity and confusion in scholarship on Urartian archaeology. The level of destruction can be identified further by taking into consideration the height of the mud-brick walls immediately behind the temple (Fig. 3). Especially in the vicinity of the Haldi temple, which is said to have been looted previously, ${ }^{8}$ shields with cuneiform inscriptions, cauldrons, ivory artefacts,

\footnotetext{
${ }^{6}$ This altar is displayed in the Ancient Orient (Eski Şark Eserleri) Museum of the Istanbul Archaeological Museums.

${ }^{7}$ There is no written information about this temple, therefore its plan must have been the reason why it was defined as a Haldi temple.

${ }^{8}$ Another document (A\} MKT. UM. 346/5), dated 4 Şaban $1275 /$ March $9^{\text {th }} 1859$ and sent to the center by the governor of the province of Van and Hakkari, is also noteworthy; it reports that the local inhabitants unearthed a cave while
}

mining stones from a mountain called Mount Akköprü at a distance of one hour from the village of Van. It also reports that water pitchers made of red clay were found in this cave, and people nearby started excavations at the spot upon hearing these news. The place was reported to be in a mountain that belonged to the state treasury, and was not the property of anyone of the local people. The document notes that workers, ropes and officials were sent to the area to excavate for five or six days. It emphasizes that the place 


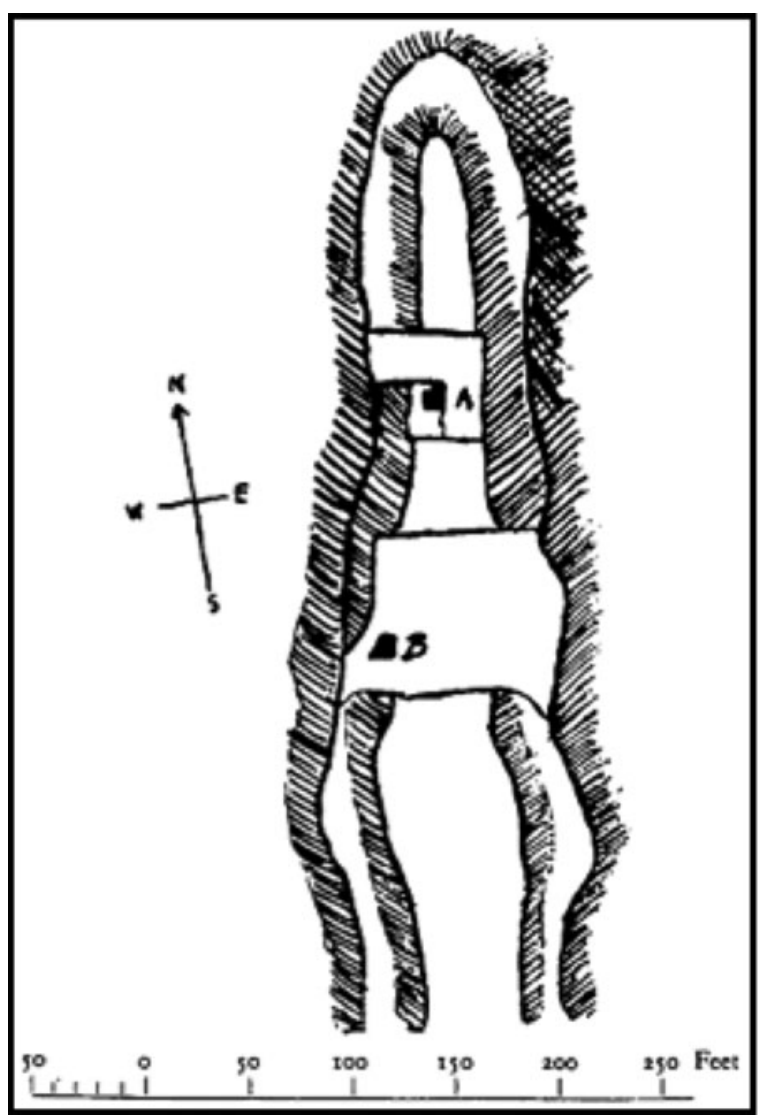

Fig. 2 The sketch of Toprakkale drawn by Clayton (Barnett 1950: 9, Fig. 5)

and bronze throne fragments were discovered (Barnett 1982: 317). The bronze fragments mentioned by Clayton and Rassam, which were thought to belong to a throne, are open to discussion. They are different from those said to have been purchased by Layard.

It is possible that as early as 1860 Layard was aware of finds similar to those he purchased in 1877, which eventually triggered the excavations. At this point, two documents in the Ottoman Archives that are related to Layard are worth mentioning (Table 1). The first is the letter sent by the British Ambassador, Sir Henry Bulwer, to the Ottoman Ministry of Foreign Affairs on June 10th, 1860 (Fig. $4=$ Document 1), in which the Ottoman Empire is praised for its contribution to Layard's work at Nimrud. The document also cautions about the protection of several artefacts said to have been discovered in the vicinity of Van, which primarily consist of "a bronze bull -one-third of the size of the animal- with a human head and a bull's body, one large eagle and two carved snakes". In the letter, it is said that the governor of the province was unaware of the value of these artefacts and had some of them melted to make use of their metal - therefore a request is made that an order be sent to him in order to prevent the destruction of these artefacts.

Sublime Port's assistance to Monseiur Layard's research, which unearthed numerous ancient artifacts several years ago, has been appreciated by the British state. I will not hesitate to request the protection of

was visited and inspected and fragments of an ancient water pitcher and some pitchers suitable for use, as well as pithos fragments and badly corroded iron fragments and some remains of an old brick building were found. Based on these remains, the place was said to belong to an ancient small fortress of several houses. The document noted that the excavations could not be completed because of heavy snow at the time, and that any future finds would be reported. Mount Akköprü mentioned in this document, and the stones, cave and finds such as red pitchers and iron fragments remind one of Toprakkale. Toprakkale was probably excavated for stone blocks and looted since early periods. 


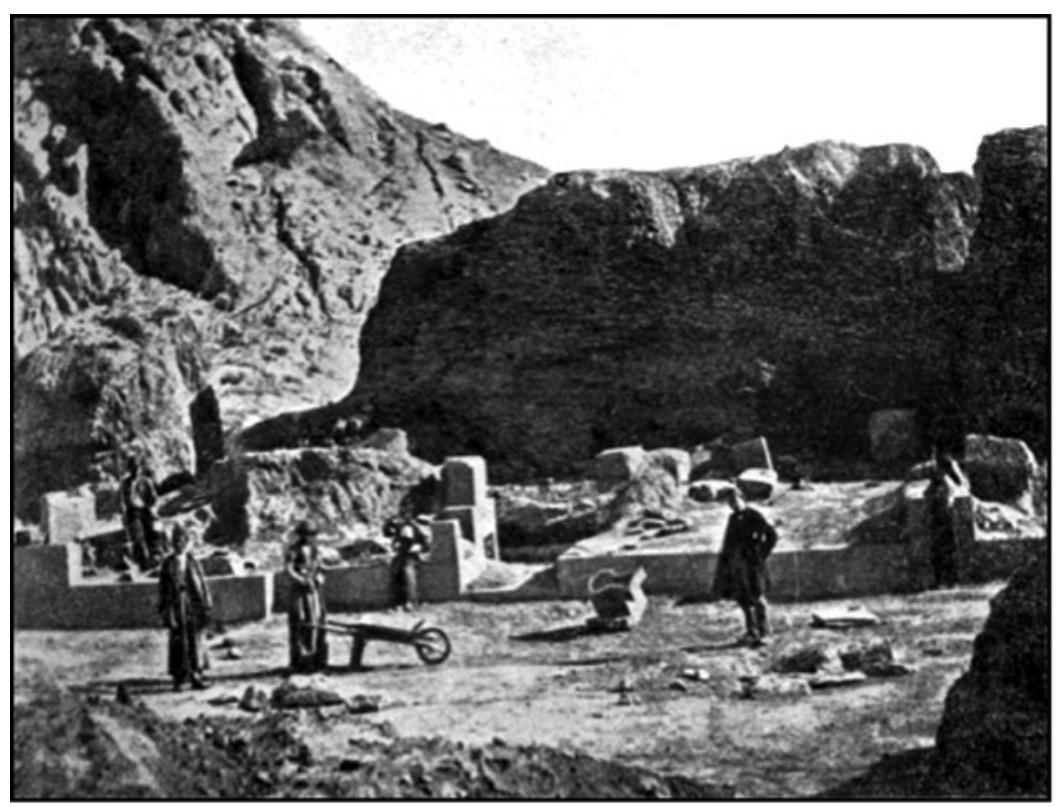

Fig. 3 The excavation of the Haldi temple at Toprakkale (Rassam 1897: 376-377)

some artifacts recently discovered around Van. Since ancient artifacts, consisting mainly of a bull made of bronze at one-third of the size of a bull and with the head of a man, a large eagle, and two serpents with carved surfaces, the value of which was apparently not understood by the governor of the land, the pasha, have reportedly been melted to utilize its metal; such artifacts should not be wasted anymore; an order should be written on this matter and sent to the pasha. ${ }^{9}$

Subsequent to this letter, Seyid Mehmed Emin Ali sent a report to Kenan Pasha, the kaymakam (district governor) of Van, on August $6^{\text {th }}, 1860 / 18$ Muharrem 1277, which refers to the ancient artefacts (Asar-ı Atika) discovered recently by Layard in Van, stating that they were aware that several of the finds, which included a bronze bull, a large eagle, and two snakes, had been melted for their metal. The letter emphasises the local government's role in the protection of such ancient artefacts and encourages awareness of their value and of their ongoing destruction. The correspondence also states that subsequently discovered ancient artefacts should be safeguarded in a proper place (Fig. 5= Document 2). These documents demonstrate the Ottoman Empire's approach towards ancient artefacts as early as the 1860 s, especially in relation to their preservation.

It has been reported that some of the ancient artifacts that were recently discovered by British Monsieur Layard around Van, which had been left to the government, including a bull, a large eagle and two serpents made of bronze, were melted down to utilize their metal. It is not a right conduct at all for the local government to melt and destroy such ancient artifacts when they should protect them instead, since they do not understand their value. Ancient artifacts should be safeguarded in a proper place from now on. ${ }^{10}$

These two documents thus may suggest that Layard knew of the bronze artefacts discovered in the vicinity of Van in 1860. Especially, the bronze bull, one-third of actual size, is among those found by Layard and left to the government as its share. It is not known, however, where these items were found. Layard, describing his excavation at the Treasure Gate/Analıkız, does not refer to any finds or artefacts (Layard 1853: 399). The human-headed bull-shaped artefact calls to mind the human-headed and winged bull said to have been found in Toprakkale and purchased by Layard in 1877 (Barnett 1950: 6, Plate 6). Considering that Layard was aware of bronze human-headed bull figurines as early as the 1860s suggests that he did not send Rassam to Toprakkale (Rassam

\footnotetext{
${ }^{9}$ HR. MKT. 344/44, 18 Muharrem $1277 /$ August $6{ }^{\text {th }}, 1860 . \quad{ }_{10}^{10}$ HR. MKT. 362/50, 18 Muharrem 1277 / August $6{ }^{\text {th }}$,
} 


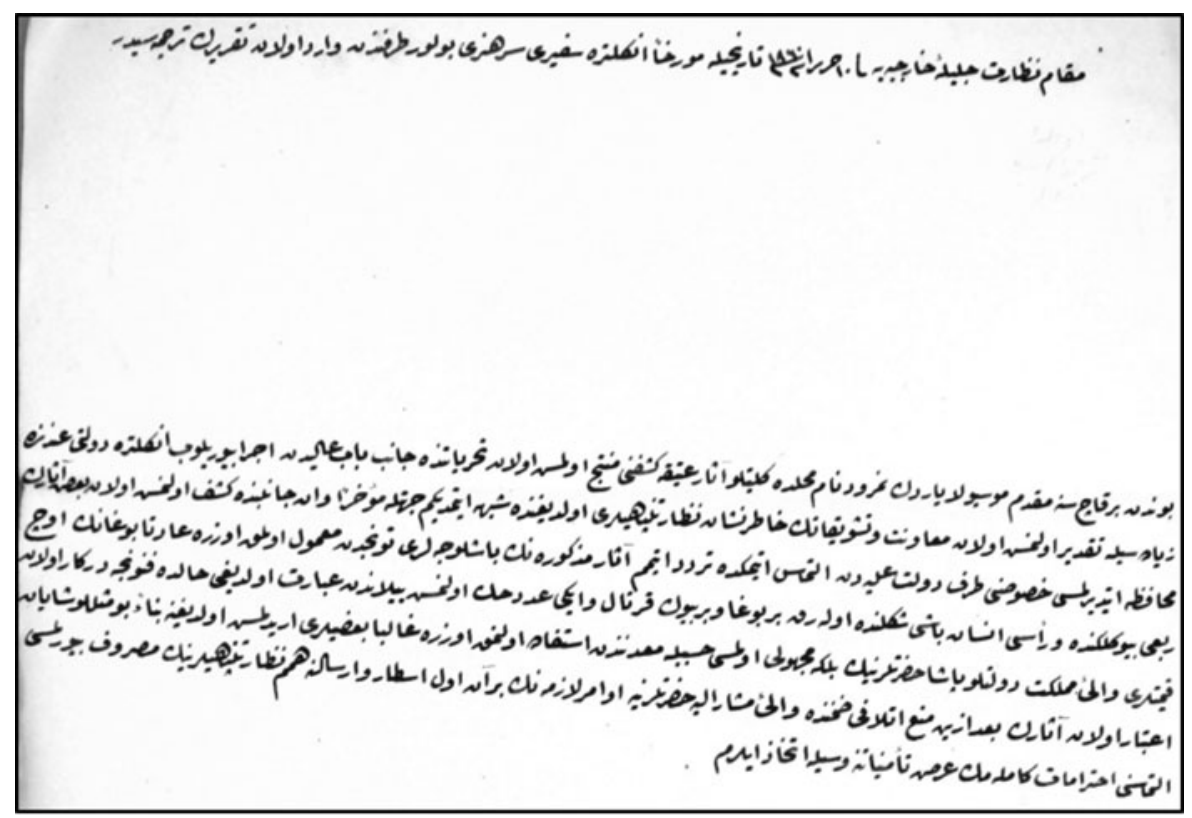

Fig. 4 Document 1 (HR. MKT. 344/44, 18 Muharrem $1277 /$ August $6^{\text {th }}, 1860$ )

1897: 111-130) only because he was curious about the origins of the items he bought in Istanbul. It is suggested that he knew the Van region and its geography well, and had found similar artefacts in Van before. We should especially keep in mind the possibility that Layard formed relationships with various teams in Van in 1849, while he was working there, or that he may have had them supervised.

There is correspondence showing that Rassam planned excavating other areas prior to his arrival in Van in 1877. He had applied for a permit to excavate and research ancient artefacts in the Diyarbekir province on behalf of the British on February $24^{\text {th }}, 1877$ / 10 Safer 1294, but his application was rejected. The reasons cited included that Diyarbekir was a large province consisting of several kazas and livas, and that the area called Assyria was located between Diyarbekir and Mosul, that Ceziretülarab and Diyarbekir were in opposite directions and quite distant, and that therefore the permit request was against the Law on Ancient Artefacts. The law stated that excavations could be conducted only within villages or districts, and that excavations could not exceed their boundaries, ${ }^{11}$ therefore Rassam is primarily asked to define more precisely where he would be excavating. ${ }^{12}$ In the correspondence of September $15^{\text {th }}, 1877 / 7$ Ramazan 1294 and November 22 $2^{\text {nd }}, 1877$ / 16 Zilkade 1294, the British Ambassador Layard requests a research permit on behalf of Rassam to investigate Nineveh. The permit is granted ${ }^{13}$ on the condition that excavated finds should be shared between the government and Rassam, in accordance with the law. ${ }^{14}$ Referring to Layard's previous explorations and research in Nineveh, Assyria and Babylon, in the correspondence of December $13^{\text {th }}, 1877 / 7$ Zilhicce 1294 and December $30^{\text {th }}, 1877 / 21$ Zilhicce 1294, a new permit is requested on behalf of the British Museum. ${ }^{15}$

Rassam was granted a permit on February $14^{\text {th }}, 1878 / 2$ Şubat 1293 to explore ancient artefacts in Mosul. ${ }^{16}$ A separate order clearly defined the rules to be abided by and the responsibilities of the officials who were to accompany the expedition. It stated in particular that the finds were to be

\footnotetext{
${ }^{11}$ Article 13 of the Ancient Monuments Act of 1874 states that the excavation area has to be shown on a map and that its boundaries cannot exceed the borders of a village or district (Çal 2003: 263).

${ }_{12}$ MF. MKT. 46/113, March 1293 / March 1877.

13 I.DH. 756/61682, 7 Ramazan $1294 /$ September $15^{\text {th }}$, 1877; MF. MKT. 51/180, 16 Zilkade 1294 / November $22^{\text {nd }}$, 1877.
}

\footnotetext{
${ }^{14}$ Article 32 of the Ancient Monuments Act of 1874 states that one third of the discovered artefacts are left to the excavator (Çal 1997: 392; Eriş 2012: 29).

${ }^{15}$ MF. MKT. 52/75, 21 Zilhicce 1294 / December $27^{\text {th }}$, 1877; MF. MKT. 52/75, 21 Zilhicce 1294 / December 30 th 1877.

${ }^{16}$ MF. MKT. 55/11, 2 Şubat 1293 / February $14^{\text {th }}, 1878$. Rassam, however, states that he began his excavations in
} 


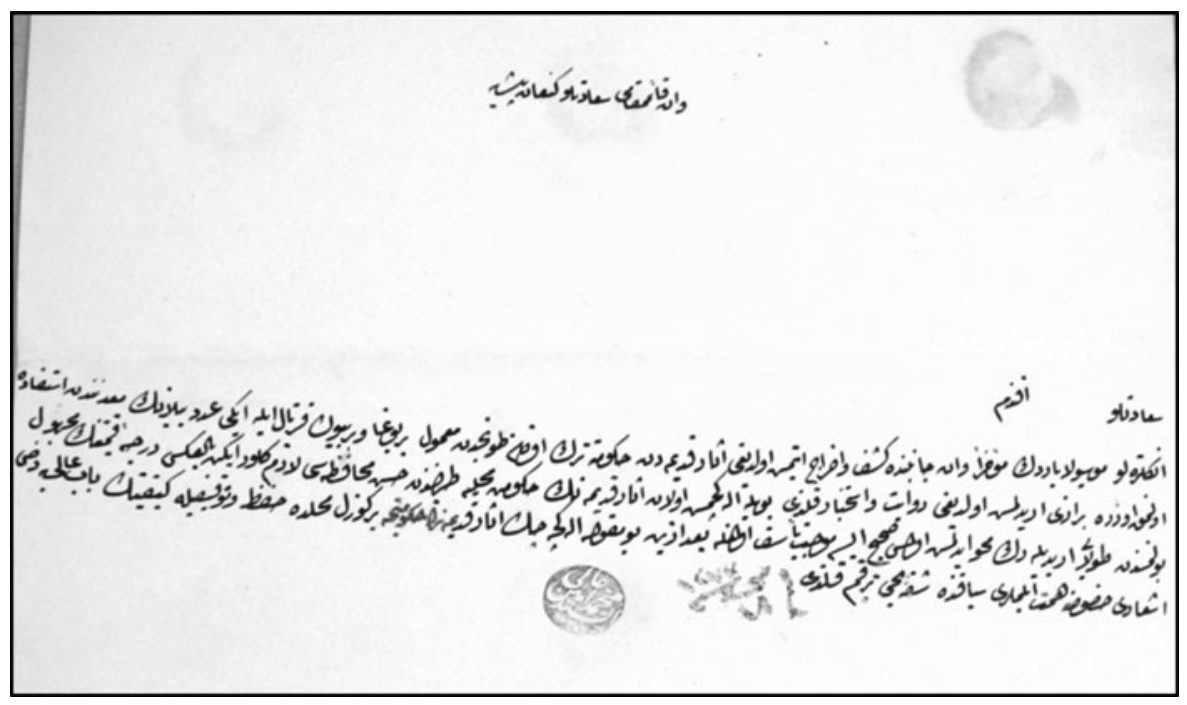

Fig. 5 Document 2 (HR. MKT. 362/50, 18 Muharrem $1277 /$ August $6^{\text {th }}, 1860$ )

recorded in two books. One of each of those artifacts that had duplicates or otherwise could be divided would be left to the Ottoman State. The prices of those artifacts that could not be divided would be defined by the local administration, and shared equally between the Ottoman State and the British Museum. For this reason, one notebook was to be kept by the official, and the other by Rassam - so that each item could be recorded daily, in terms of number and type - and signed by both parties. ${ }^{17}$ A report sent to the priest Sebilyan Efendi, an official who accompanied Rassam, states that Rassam was carrying out research on behalf of the state and that the artifacts which would go to the State Treasury among the artifacts that he would excavate had already been identified, and therefore that he should be distinguished from other researchers and his research and explorations should not be unnecessarily hindered. ${ }^{18}$ In a report dated May $11^{\text {th }}, 1878 / 9$ Cemazeyilevvel 1295, concerning staff salaries sent to the Sublime Porte, Rasssam is understood to be continuing his excavations in the vicinity of Mosul; ${ }^{19}$ however, in a document dated October $17^{\text {th }}, 1878 / 20$ Şevval 1295, it is stated that Rassam had excavated in Mosul ${ }^{20}$ and that he was waiting for the renewal of the December $3^{\text {rd }}, 1878 / 8$ Zilhicce 1295 firman, given subsequent to Layard's request. ${ }^{21}$ In a telegram sent to the Baghdad province on May $6^{\text {th }}, 1882$ / 24 Nisan 1298, it is noted that the Embassy had reported that Rassam's work was being hindered and that he should be treated in accordance with the firman. ${ }^{22}$ Layard in particular expedited bureaucratic processes such as the excavation permits which were necessary for Rassam to carry out excavations and thus enabled him to continue work.

Layard and Rassam conducted excavations in several Assyrian settlements between 1877 and 1882. The prospects for Toprakkale were enhanced when in 1880 the province of Van was included in these excavations. A firman, dated August $16^{\text {th }}, 1880 / 10$ Ramazan 1297 and addressing the governors of Baghdad, Van and Aleppo, granted Rassam the permit - on behalf of the British Museum and Layard - to explore an extensive region that included also Van. It can be assumed that excavations in Toprakkale began after this date.

Kuyunjik on January $7^{\text {th }}$, 1878: 24 years after he first excavated in Mosul in 1852-1854 (Rassam 1897: 199-200).

${ }^{17}$ MF. MKT. 55/104, 17 Rabiulahir 1295 / April $20^{\text {th }} 1878$; MF. MKT. 55/62, 17 Rabiulahir 1295/ April 20 th 1878 ; MF. MKT. 55/62, 8 Nisan $1294 /$ April $20^{\text {th }} 1878$.

${ }^{18}$ MF. MKT. 55/141, 27 Rabiulahir $1295 /$ April $30^{\text {th }} 1878$.
${ }^{19}$ MF. MKT. 56/49, 9 Cemazeyilevvel $1295 /$ May $11^{\text {th }}$ 1878. Rassam mentions that artifacts were packed for a long journey to the British Museum starting on May $17^{\text {th }}$ 1878 (Rassam 1897: 229).

${ }^{20}$ MF. MKT. 58/51, 20 Şevval $1295 /$ October $17^{\text {th }}, 1878$.

${ }^{21}$ HR. TO. 261/40, 8 Zilhicce 1295 / December $3^{\text {rd }}, 1878$.

${ }^{22}$ MF. MKT. 75/142, 24 Nisan 1298 / May $6^{\text {th }}, 1882$. 
The British Embassy, in a correspondence dated December $15^{\text {th }}, 1882$ / 3 Kanunuevvel 1298, applied for the renewal of the permit. The correspondence notes that the firman dated August $16^{\text {th }}, 1880$ / 10 Ramazan 1297 and addressed to the governors of Baghdad, Van and Aleppo, which granted permission to Rassam for research on antiquities on behalf of the British Museum, had expired. Citing the hitherto fruitless communications of the Ambassador in this regard, the letter warns that unless the permit is renewed, this costly excavation will remain unfinished. Subsequent correspondence demonstrates that the Ministry of Foreign Affairs (Hariciye Nezareti) extended the duration of the permit based on the previous firman, on the condition that related regulations are abided by (Document $3=$ Fig. 6 ) ${ }^{23}$

A letter dated March 25 ${ }^{\text {th }}, 1884$ / 27 Cemazeyilevvel 1301, however, contains another request for renewal of the firman dated August $16^{\text {th }}, 1880 / 10$ Ramazan 1297, which granted concessions to Layard for the exploration of ancient artefacts in Van, Aleppo and Baghdad. Stating that previous applications to the Sublime Porte had not amounted to any successful result, a new request is put forward for the renewal of Layard's permit and for the issue to be raised with the Sultan. ${ }^{24}$

The renewal of the original permit of 1880 is a constant cause of correspondence between the Embassy and the Sublime Porte. There is a discrepancy, however, between the date of the permit issued to Layard, and the dates when Dr Reynolds and Captain Emilius Clayton, British ViceConsul -charged with digging Toprakkale by Rassam - began their excavations. We have mentioned that in 1880 Clayton and Reynolds carried out a short-term excavation in Toprakkale under Rassam's supervision as he was digging in various Assyrian settlements (Barnett 1972: 163). Clayton, however, in a letter addressed to Layard on May $11^{\text {th }}$, 1880 , states that he began excavating on March $3^{\text {rd }}$ but had to stop within a few days owing to a number of factors including weather conditions (Barnett 1950: 9; Zimansky 2011: 59-60). As Clayton mentions, weather conditions would have made it unlikely to be able to excavate Toprakkale in March. The fact that the permit started in August rules out the possibility of earlier excavations and therefore Clayton's starting date becomes disputable.

K. Kamsarakan. An illegal excavation was carried out at Toprakkale following Rassam's excavation. The letter Reynolds penned to Birch on June $24^{\text {th }}$, 1884 from Van is significant in terms of the information it provides on this dig and the finds (Barnett 1950: 20-21):

\begin{abstract}
Yesterday a working man who has been doing some excavating on his own hook in the vicinity of the trenches Mr. Rassam opened when here, brought a bronze image in very perfect preservation. The body is that of a lion, with wings, but the rest of the body not feathered. To this is added a human head, shoulders and hands, the latter folded in front. The face is ivory. If you received my former letter containing the description and figures of images for sale here, this resembles one there figured but is a little smaller, about 7 inches (17.7 centimetres) long and 5 inches (12.6 centimetres) high.
\end{abstract}

Barnett identified the winged sphinx with the body of a lion mentioned in the letter as one of the bronze figurines in the Hermitage (Barnett 1954: 19), which was published by Piotrovsky 25 (Piotrovsky 1967: 28, Fig. 15). Piotrovsky relays an important acquisition recorded by F.G. Bernshtam in the Hermitage archives of 1885:

Sold to me for the Department of Antiquities of the Hermitage for 3,000 roubles the following Assyrian objects, to wit: 1 silver bracelet (with lion heads), 1 similar of bronze but broken, 1 bronze winged lion with human head of alabaster, 1 bronze goat with damaged face, 1 bronze staff end, 1 bronze ring, 1 piece of bronze armour, bronze fragments and several pieces of alabaster. All these found by Mr. K. Kamsarakan at Van on the hill of Toprakkale in $1884 .^{26}$

\footnotetext{
${ }^{23}$ MF. MKT. 79/79, 4 Cemazeyilevvel $1300 /$ March $13^{\text {th }}$ 1883.

${ }^{24}$ Y. PRK. EŞA. 4/14, 27 Cemazeyilevvel $1301 /$ March $25^{\text {th }} 1884$.

${ }^{25}$ For these bronze figurines in the Hermitage Museum see Piotrovsky 1967: 25, Fig. 9; 28, Fig. 14-15; 31, Fig. 18c.
}

\footnotetext{
${ }^{26}$ Piotrovsky 1967: 28. The figurines (said to belong to a throne) (Barnett 1950: 43; Seidl 1994: 67-84; Seidl 1996: 185-186) and other finds discovered in Toprakkale have no parallels in other Urartian temples.
} 


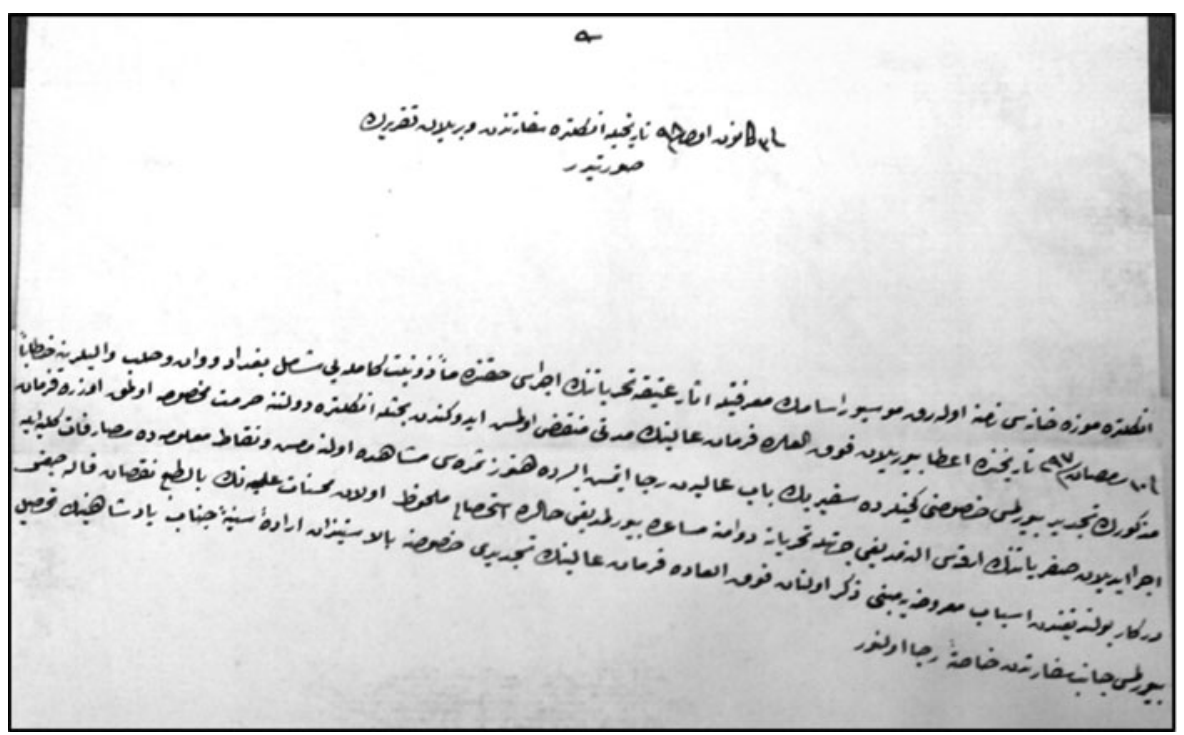

Fig. 6 Document 3 (MF. MKT. 79/79, 4 Cemazeyilevvel $1300 /$ March $13^{\text {th }} 1883$ )

The winged bronze lion with an alabaster human head (inventory no: 16002) is identified as a sphinx, while the bronze goat with a damaged face is considered to be a winged bull (inventory no: 16001) (Barnett 1954: 19). Barnett also states that the identity of one of the people referred to in Reynolds' letter to Birch is likely to be some sort of a special attendant or employee, either Sedrak Devgants ${ }^{27}$ or Kamsarakan, the Russian consul in Van. Two photographs of Toprakkale dating to 1881 that we have discovered are extremely significant in this regard. The photograph of Mrs Kamsarakan ${ }^{28}$ with Mr. Gaillard, who was the chief of the international telegram service in Van, in front of the Temple of Haldi in Toprakkale demonstrates the Kamsarakan's interest in the site (Figs. 7-8).

The "working man" referred to in Reynolds' letter to Birch, dated June $20^{\text {th }}, 1884$, may be associated with Devgants, who himself excavated near Rassam's trenches and unearthed a bronze

\footnotetext{
${ }^{27}$ In Sedrak Devgants' letters to professor K. Patnakoff, he gives a list of artefacts he found among the ruins of the fortress, which he named "Zem Zem Cave", and describes their types. For further detail see Barnett 1950: 3-8; Barnett 1954: 16-19; Piotrovsky 1969: 17. It is plausible that Sedrak Devgants was the person who in 1877 sold several "Assyrian artefacts" from Van to Layard in Istanbul. Of these artefacts, considered to be two figurines of a throne, one is a winged bull on its knees and the other is a standing winged bull with a human front. Sedrak Devgants seems to have known of Toprakkale before Reynolds and Clayton's excavations and played a key role in the dispersal of the finds across several countries through the excavations he carried out. It appears as if his friendship with $\mathrm{K}$. Kamsarakan resulted in some finds ending up in Russia. Interesting here is that the artefacts sold to Layard in 1877 as well as the artefacts mentioned in Reynolds' letter to Birch in 1884, and those that Kamsarakan says he found in Toprakkale are all said to belong to a throne. That the Toprakkale artefacts unearthed in 1877-1884 through legal and illicit excavations should all come from a throne presents a highly suspicious situation. In the event that Sedrak Devgants was the person who originally sold the items to Layard, and his relationship with Kamsarakan make the case for the location of the finds all the more problematic. Also, Rassam's own letters attest to the fact
}

that he knew the Kamsarakans (M. and Madame Komsaragan) (Rassam 1897: 380).

${ }^{28}$ Chantre and Barry 1881: F. 22. Paul Müller-Simonis and Henri Hyvernat, who visited Toprakkale, refer to the location of the site, its construction system and decaying mudbrick, and mention that the excavation was supervised by Chantre and Barry in collaboration with the British. They state that work had ceased but that the trenches were intact. They also mention the photographs, shown to them by Reynolds, of bronze artefacts discovered during the excavation and note Hyvernat's interest in purchasing an attractive piece of bronze shield from Toprakkale. They emphasize Elisee Reclus' mention of Chantre as the supervisor of the Toprakkale excavation. Müller-Simonis and Hyvernat state that they do not know when the excavation was carried out and that Chantre had told them he was unable to continue owing to time constraints (Müller-Simonis - Hyvernat 1892: 193-194). Reclus, on the other hand, defines Toprakkale as an Assyrian fortress with towers and basalt walls, and states that it was discovered by Chantre and Barry (Reclus 1876: 190). Considering that Chantre and Barry discovered the site in 1876, and remembering their two photographs taken in front of the temple at Toprakkale, we can deduce that Chantre and Barry remained interested in the site for a long time. 


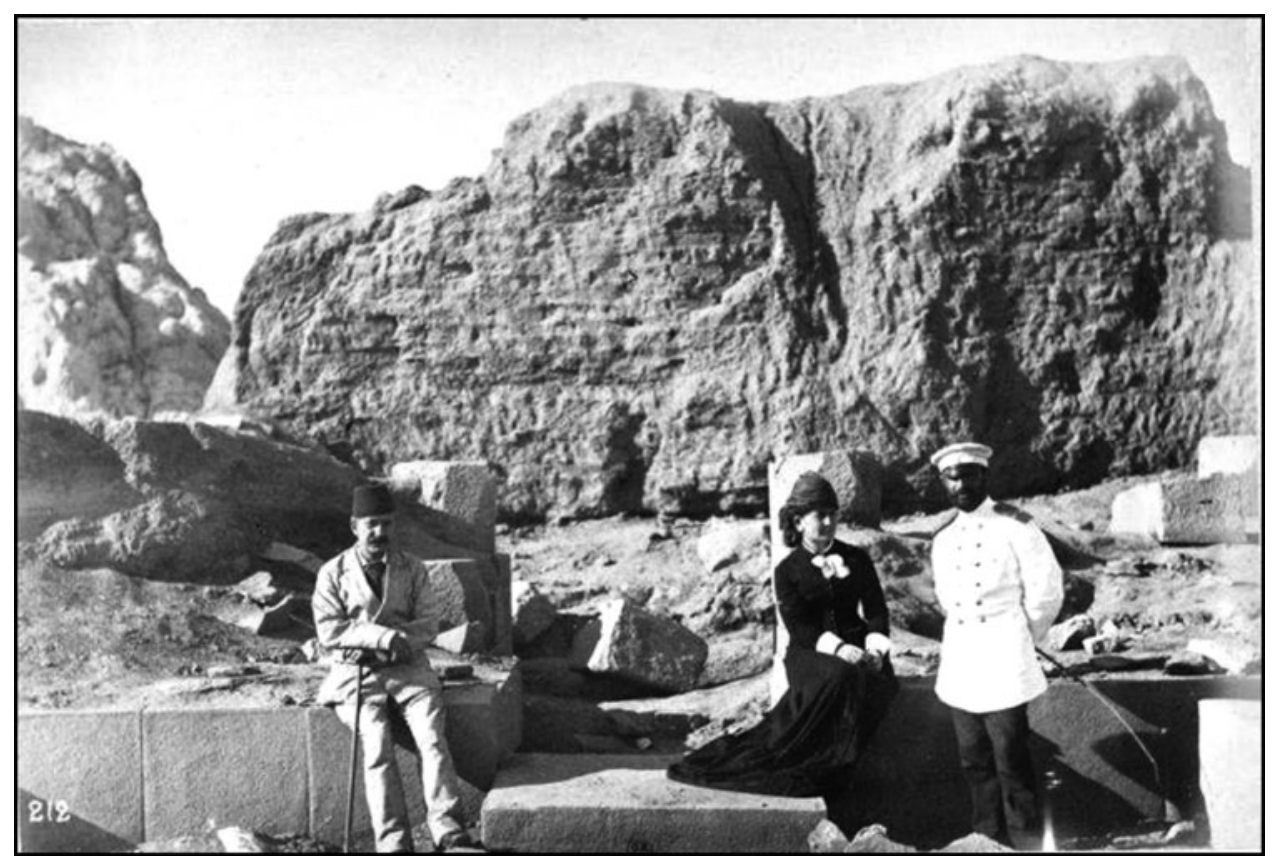

Fig. 7 Mr. Gaillard and Madam Kamsarakan, in front of Haldi Temple at Toprakkale (Chantre and Barry 1881: F. 22)

statue, which was said to be in pristine condition. He was known to be an antiquities dealer who sold items abroad via places like Astwadzaschen ${ }^{29}$ and Dzevesdan ${ }^{30}$ (Müller 1885: 24; Müller 1886: 158; Piotrovsky 1969: 17). The artefacts Devgants claimed that he found in Toprakkale, his relationship with the Kamsarakans, and the fact that he was selling artefacts, make the context of the archaeological finds rather questionable.

Carl Ferdinand Friedrich Lehmann-Haupt and Waldemar Belck. Previous scholarship generally accepts that Lehmann-Haupt and Belck excavated at Toprakkale in 1898-1899 (Barnett 1950: 23; Öğün 1961: 265; Piotrovsky 1969: 19; Sekmen 1990: 30; Wartke 1990: 8; Sevin 2003: 4; Salvini 2006: 18; Koçak 2011: 90-91; Tarhan 2011: 295; Zimansky 2011: 60-61). It is even suggested that they excavated over two consecutive seasons in 1898 and 1899 (Erzen et al. 1960b: 5). However, in their report to the Anthropologische und Ethnologische Gesellschaft Berlin, dated October $5^{\text {th }}$, 1898, Lehmann-Haupt and Belck state that they came to Van on September $24^{\text {th }}$ (Belck and Lehmann-Haupt 1898: 416). In the same publication, in a report dated December $5^{\text {th }}, 1898$, they state that they reached Van on September $24^{\text {th }}, 1898$, and began preparing for the excavation a week later, on September $30^{\text {th }}, 1898$ (Belck and Lehmann-Haupt 1898: 578-579). ${ }^{31}$ In a joint report penned on November $30^{\text {th }}, 1898$, they state that they had been excavating at Toprakkale for almost two months with 80 to 100 workers (Belck - Lehmann-Haupt 1898: 578). In his subsequent publication, however, Lehmann-Haupt gives December $30^{\text {th }}, 1898$ as the starting date of the excavation (Lehmann-Haupt 1931: 457). Considering the incredibly harsh winter conditions in Van, especially from December onwards and continuing well into March, it would have been impossible for them to carry out an excavation during this season. As this rather refutes the

\footnotetext{
${ }^{29}$ Astwadzaschen/Asbaşin is the modern Çavuştepe village (Lehmann-Haupt 1926: 60; Kevorkian - Paboudjian 2012: 539).

${ }^{30}$ Dzevesdan or Dzvisdan/Zevistan is the modern Zivistan/ Elmalık village (Kevorkian - Paboudjian 2012: 537). Inscribed column bases of Išpuini were found here (CTU A

$2-2 \mathrm{~A}-\mathrm{G}$ ), which refer to a building (E) constructed by Išpuini, son of Sarduri.

${ }^{31}$ Belck - Lehmann-Haupt 1898: 579; They state that they began excavating with 20 workers and increased their number quite quickly to 80 and then 100 (they were increasing the number of workers by 20 every two days).
} 


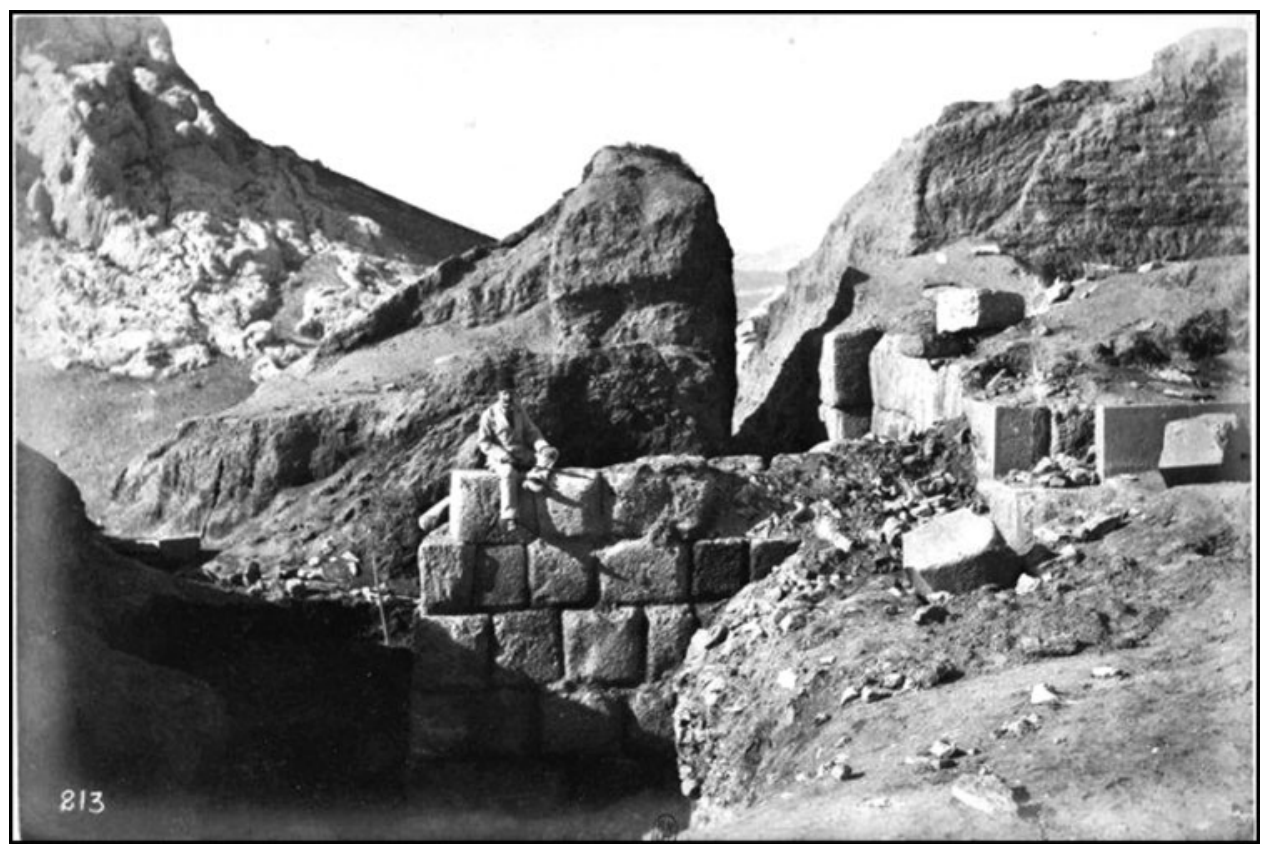

Fig. 8 Mr. Gaillard sitting on the wall of Haldi Temple at Toprakkale (Chantre and Barry 1881: F. 21)

December date, it would be wrong to suggest that they arrived in Van and began excavating in December (Sekmen 1990: 32; Sevin 2003: 4). It is necessary to study the relevant Ottoman correspondence on Lehmann-Haupt and Belck in order to clarify whether they actually excavated on that date, or whether indeed the excavation had been continuing for two months in December, and for how long they excavated and what the conditions were (Table 2).

We have found various documents concerning the excavations carried out by Lehmann-Haupt and Belck in 1898-1899, including permits, in the Ottoman Archives of the office of the Prime Minister. These documents cover the years between 1898 and 1902, but those that relate to 1898 and 1899 need to be scrutinized separately.

Dated April $7^{\text {th }}, 1898 /$ March $26^{\text {th }}, 1314$ the earliest document is written in connection with a telegram sent from the German Embassy regarding Dr. Lehmann and Dr. Belck's impending explorations in Baghdad, Mosul, Van, Mamuretülaziz, Erzurum, Bitlis and Trabzon.

The document was sent to 14 provinces via the Interior, Foreign Affairs and Education ministries (Dâhiliye, Hariciye ve Maarif Nezareti) and instructed governors to aid Lehmann(-Haupt) and Belck in their pursuits. In the other two letters, dated April $13^{\text {th }}, 1898 / 21$ Zilkade 1315 and May $13^{\text {th }}, 1898 /$ 21 Zilhicce $1315^{32}$ and another dated May $9^{\text {th }}, 1898 / 17$ Zilhicce $1315,{ }^{33}$ the same content requesting help regarding the research they would carry out in 7 provinces is reiterated.

In a letter dated May $23^{\text {rd }}, 1898$ / 2 Muharrem 1316, Osman Hamdi Bey, the director of the Imperial Museum, informs the Education Ministry of the nature of this exploration. $\mathrm{He}$ emphasizes that Dr. Lehmann and Dr. Belck are allowed to investigate ancient artefacts, the origin of species, and natural sciences, and have the necessary permit to carry out surface surveys in the provinces of Baghdad, Mosul, Van, Bitlis, Mamuretülaziz, Erzurum and Trabzon. He especially notes the reports that were circulating about them intending to excavate, but that unless they met the requirements in the regulation ${ }^{34}$ (Asar-1 Atika Nizamnamesi/Antiquities Law), they

\footnotetext{
${ }^{32}$ BOA. İ.HR. 358/45, 16 Zilhicce 1315/8 May1s 1898.

${ }_{33}$ BEO. 1122/84128, 20 Zilhicce 1315/12 May1s 1898.

${ }^{34} \mathrm{As}$ in the regulations of $1869 / 1$ and $1874 / 7$, the $1884 / 7$ regulation also clearly defines the conditions for excavations
}

(Çal 2003: 259-260). No one was allowed to carry out a survey or excavation of ancient artefacts on Ottoman soil without prior official permit within the scope of the 1884 regulation (Eriş 2012: 39). 


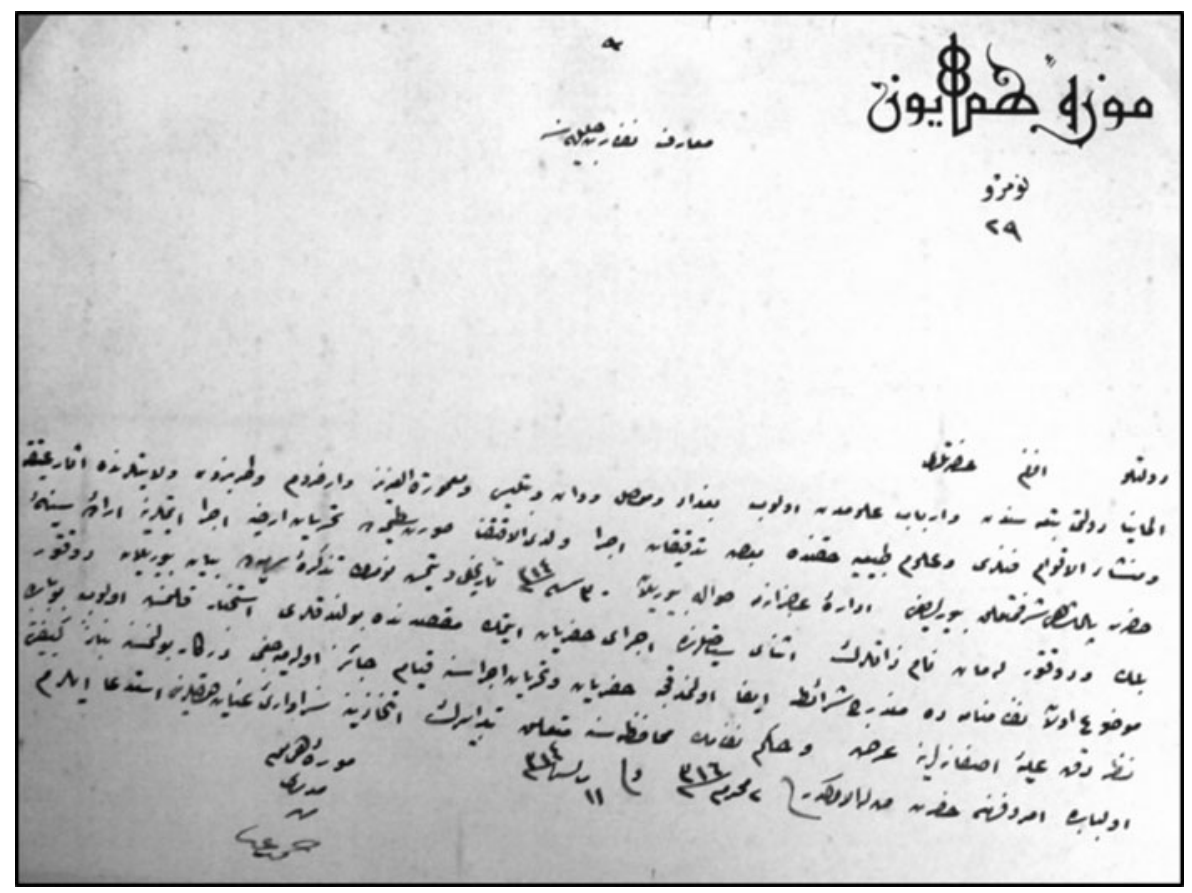

Fig. 9 Document 4 (MKT. 397/1, 2 Muharrem 1316/23 Mayıs 1898)

would not be in a position to do so (Document $4=$ Fig. 9). ${ }^{35}$ Both the Antiquities Law (Çal 2005: 259-260) and the scope of the research permit granted to Dr Lehmann and Dr Belck clearly illustrates this situation.

Zühdü Pasha, the Education Minister, ${ }^{36}$ in his letter dated June $11^{\text {th }}, 1898 / 21$ Muharrem 1316, states that 14 references (teveccühname) were sent to provincial governors, instructing them to facilitate Dr Lehmann and Dr Belck's explorations, who were charged by the German government with the investigation of ancient artefacts, the origin of species, and natural sciences, and carrying out surface surveys if necessary, and taking photographs. In view of the reports of their intention to excavate during their trip, it is stressed that this could only be carried out by meeting the conditions of the regulation, and that they only have the authority to carry out surface surveys. Also noted is that in the event that these reports are correct and excavation does take place, the necessary actions should be taken in order to comply with the regulation. The exact same issues are raised in a correspondence with the Ministry of Foreign Affairs, dated June $12^{\text {th }}, 1898 / 22$ Muharrem 1316, that also instructs, in order to avoid future problems, all necessary measures to be taken in the event of a possible misuse of permit. ${ }^{37}$

Subsequent correspondence between the Ministry of Foreign Affairs and the Ministry of Education, dating to July $2^{\text {nd }}, 1898$ / 12 Safer 1316 , August $2^{\text {nd }}, 1898 / 14$ Rabiulevvel 1316, and August $4^{\text {th }}, 1898$ / 16 Rabiulevvel 1316, reiterate the problems that Dr Lehmann and Dr Belck's intention to excavate might create, and instruct the Ministry of Education to take the necessary actions in advance. A letter from the Ministry of Education on July $6^{\text {th }}, 1898 / 16$ Safer 1316 , however, states that Dr. Lehmann and Dr. Belck's aim was to conduct surface surveys and that they would not attempt to excavate, and therefore, no further action was necessary. ${ }^{38}$

The letter from the Ministry of Foreign Affairs, dated November $3^{\text {rd }}, 1898$ / 18 Cemazeyilahir 1316 , presents crucial details on the history of excavations and attempts of excavation. It begins by stating that without an official permit Lehmann and Belck were not entitled to carry out

${ }_{35}^{35}$ MKT. 397/1, 2 Muharrem 1316/23 May1s 1898.

${ }_{37}^{36}$ Maarif-i Umumiye Nazırı.

${ }^{37}$ BEO. 1142/85587, 24 Muharrem 1316/14 Haziran 1898.
${ }^{38}$ BEO. 1152/86381, 16 Safer 1316/6 Temmuz 1898; BEO. 1171/87788, 18 Rabiulevvel 1316/6 Ağustos 1898. 
investigations on ancient artefacts in the provinces at stake, and that it would be illegal for them to conduct any such pursuits. Referring to a telegram sent by the local Education Accounts Directorate, which informs of two German Doctors who are going to start excavating the following day and that they will be taking the artefacts they would unearth, the letter states that this is against the regulation as well as their permit, and that under no condition should an excavation take place without further instructions (Document $5=$ Fig. 10) ${ }^{39}$

The governor of Van, Tahir Pasha, in a letter to the Ministry of Interior on November $30^{\text {th }}, 1898 / 18$ Teşrinisani 1314, shares some information he received from the police department. Using a small gadget that he was carrying on his chest, Dr. Lehmann was taking photographs of Armenian houses, burnt down during a conflict. ${ }^{40}$ On another document dated December $3^{\text {rd }}, 1898 / 19$ Receb 1316, there are instructions for Dr Lehmann and Dr Belck to follow, and in the case of an issue this should be reported secretly. The letter also asks about the necessary measures regarding the photographs Dr Lehmann took (Document $6=$ Fig. 11). ${ }^{41}$

The governor of Mosul, Hazim Pasha, in a letter to the Ministry of Education on May $2^{\text {nd }}, 1899$ / 20 Nisan 1315, refers to four inscribed stones, which Monsieur Lehmann, had unearthed by himself from the Nimrud ruin, and was in the process of transporting them. In a letter sent to the governorship of Mosul on May $6^{\text {th }}, 1899$ / 25 Zilhicce 1316, it is emphasized that Dr Lehmann and his companion's permit only allows for surface surveys, and as this does not give them the right to excavate or transport artefacts, the governorship is instructed to confiscate the items and keep them under protection at the governorship and send their photographs to the Ministry. The letter specifically emphasizes that excavations are subject to official permits in accordance with the regulation, and therefore excavations without permits should be prohibited. In another letter sent to on May $6^{\text {th }}, 1899$ / 25 Zilhicce 1316, Mehmet Tevfik the Deputy Education Director of Mosul informs the Ministry of Education that Dr Lehmann and his companion had excavated at Nimrud and that four inscribed artefacts were about to be transported, but that the stones were confiscated by the governorship and the actions of these two persons were reported in detail in two telegrams sent to the Minister of Education and the director of the Imperial Museum. A letter sent to the High School (Mekteb-i İdadi) Directorate of Mosul on July $4^{\text {th }}$, 1899 / 22 Haziran 1315, gives instructions not to let Dr Lehmann and his companion Belck excavate without a permit, and to inform the local government immediately in case foreigners or locals excavate for artefacts. ${ }^{42}$

In a letter dated September $5^{\text {th }}, 1899 / 28$ Rabiulahir 1317, there are specific instructions not to let anyone excavate for ancient artefacts without a prior permit - based on the information obtained from the governorship of Mosul, which informs about Dr Lehmann and Dr Belck's illicit excavation at Nimrud during which they unearthed four stones and brought them to Mosul. ${ }^{43}$

Lehmann-Haupt's investigations on May $23^{\text {th }}, 1899^{44}$ at the Lice-Tigris tunnel is the subject of a ciphered message sent from Diyarbekir on June $5^{\text {th }}$, 1899/24 May1s 1315, which states that Dr. Lehmann and the Russian consul in Van met at the caves in the vicinity of Lice (Tigris tunnel) and on the $16^{\text {th }}$ day of the month, on a Sunday morning, went to Çapakçur (Bingöl), in the Genç sancak of the province of Bitlis, and that Dr. Lehmann took photographs and copied the images and inscriptions at the entrances of two caves (Lehmann 1901: 226-244, Fig. 1-4). ${ }^{45}$ Another letter reports the departure of Dr Lehmann and Dr. Belck from Van on February $14^{\text {th }}, 1900 / 2$ Şubat 1315, and their arrival in Cizre on March $14^{\text {th }}, 1900 / 1$ Mart 1316, via Gevaş, Karçikan, Bitlis and Siirt, and states that Dr. Belck returned to Van and Dr. Lehmann travelled to Erzincan, stopping at Midyat, Lice, Palu, Mazgirt, Harput, Malatya, Eğin, and Kemah. ${ }^{46}$

All of the correspondence examined reveals explicitly and recurrently that the permit given to Lehmann-Haupt and Belck was for the investigation of ancient artefacts, the origin of the species,

${ }^{39}$ BEO. 1206/90387, 18 Cemazeyilahir 1316/3 Kasım 1898

${ }^{40}$ DH. ŞFR. 229/63, 18 Teşrinisani 1314/30 Kasım 1898.

41 DH. MKT. 2143/16, 19 Receb 1316/3 Aralik 1898.

42 MF. MKT. 447/47, 25 Zilhicce1316/6 May1s 1899.

${ }^{43}$ DH. MKT. 2242/130, 28 Rabiulahir 1317/5 Eylül 1899; DH. MKT. 2197/1, 29 Zilhicce 1316/10 May1s 1899; DH. MKT. 2242/130, 28 Rabiulahir 1317/5 Eylül 1899.

\footnotetext{
${ }^{44}$ For the details of Lehmann-Haupt's Tigris tunnel itinerary see Lehmann-Haupt 1910: 430-462.

${ }^{45}$ Y. PRK. UM. 46/54, 25 Muharrem 1317/5 Haziran 1899.

${ }^{46}$ DH. MKT. 2242/130, 28 Rabiulahir 1317/5 Eylül 1899. For the joint and separate itineraries of Lehmann-Haupt and Belck see (Schachner 2009: 257-261, Abb. 249).
} 


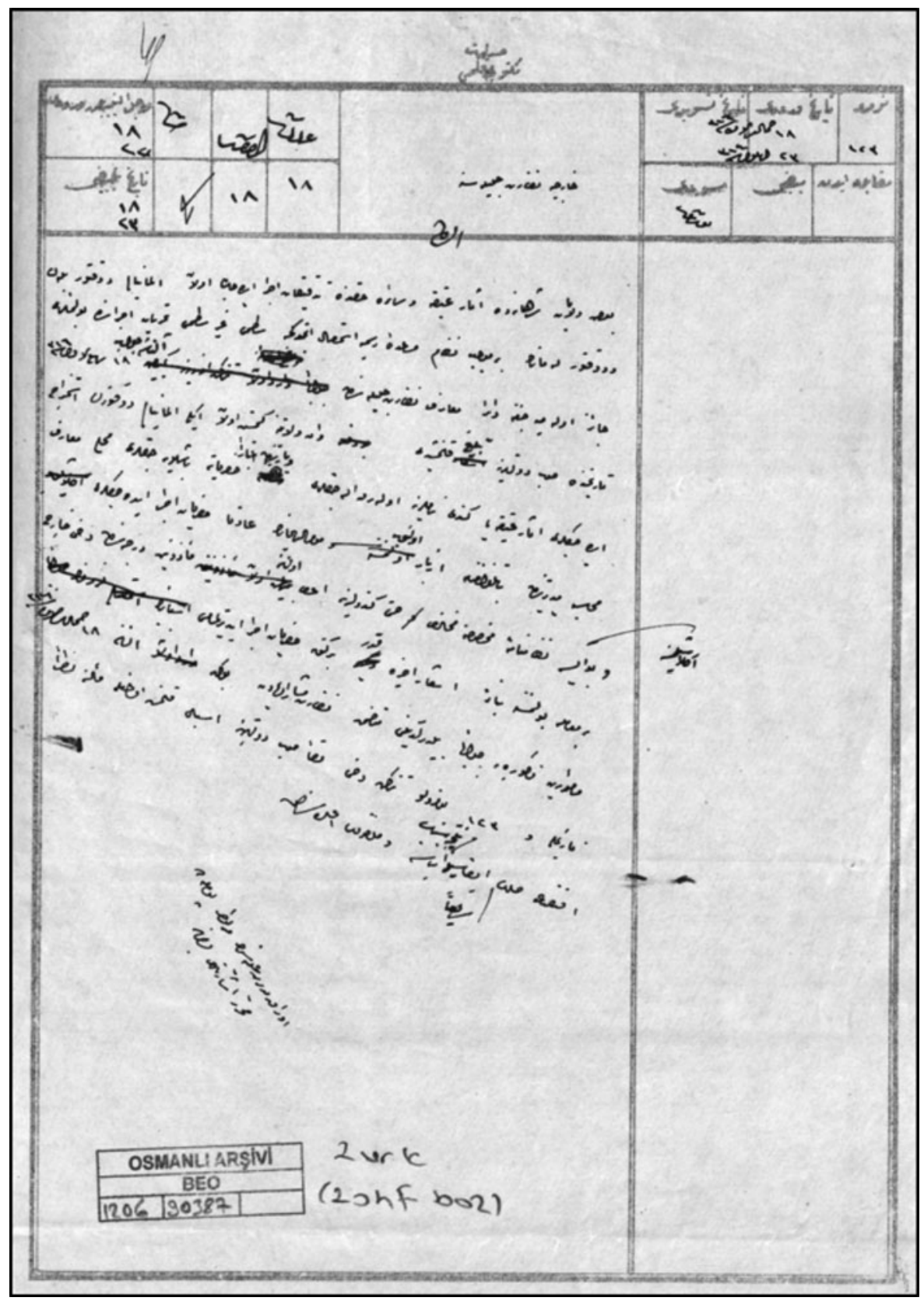

Fig. 10 Document 5 (BEO. 1206/90387, 18 Cemazeyilahir 1316/3 Kasım 1898)

and natural sciences, which if necessary could involve surface surveys and photography, in seven provinces including Baghdad, Mosul, Van, Mamuretülaziz, Erzurum, Bitlis and Trabzon. Lehmann-Haupt and Belck, on the other hand, legitimize their actions in Toprakkale by stating that they interpreted the permit in the sense of "oberflächlich ausgraben" (surface excavation) (Belck and Lehmann-Haupt 1898: 578). The documents we have introduced above, however, especially those covering the years of 1898 and 1899, clearly state that the permit they had was actually, in today's terminology, for surface surveys, that it was under no circumstances an excavation permit, and that any infringement would cause problems. These documents also plainly demonstrate contrary to previous statements (Sevin 2003: 5) the Ottoman State's interest in 


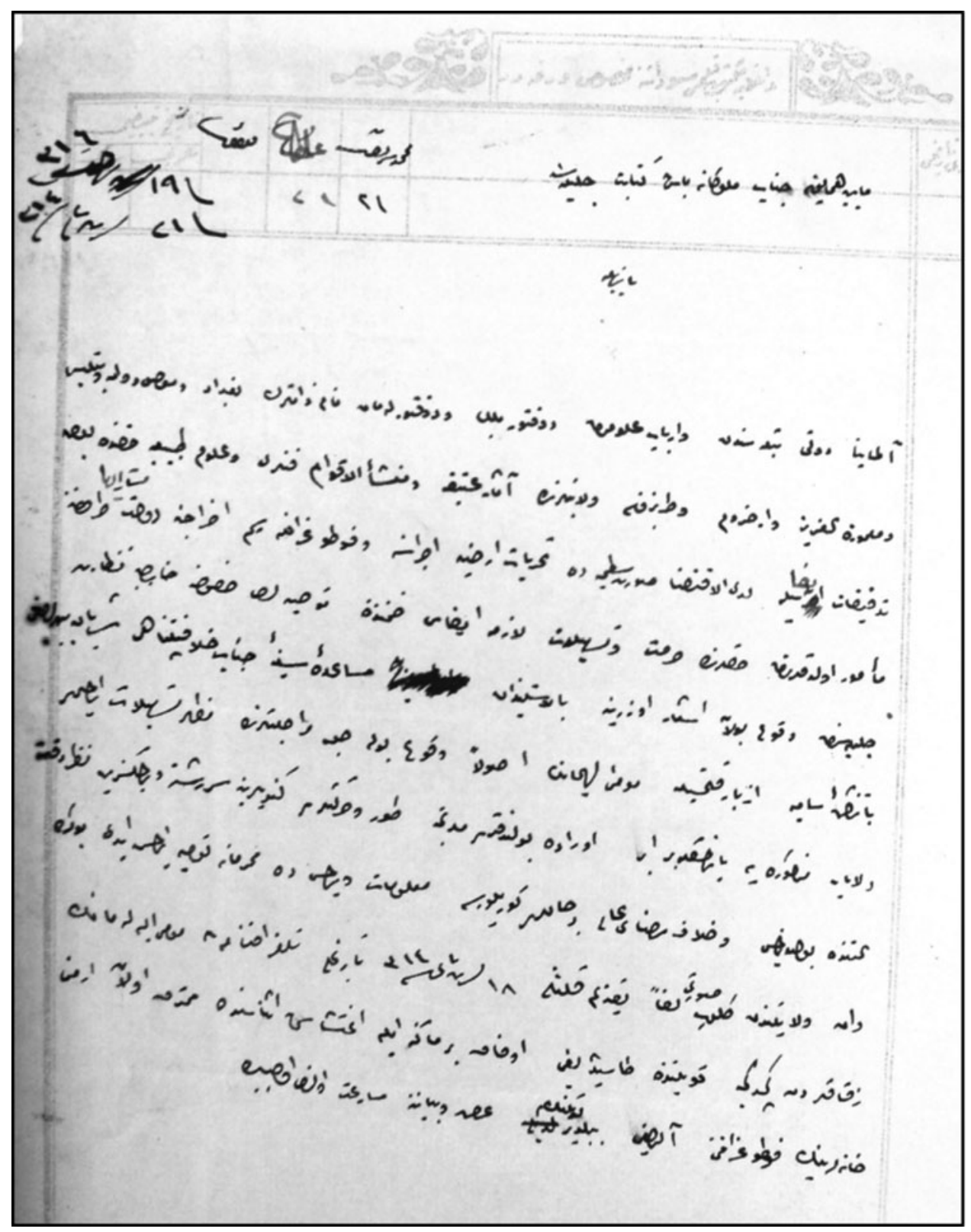

Fig. 11 Document 6 (DH. MKT. 2143/16, 19 Receb 1316/3 Aralık 1898)

archaeology, excavations and ancient artefacts, and its control mechanisms in distant provinces of the empire.

The dates Lehmann-Haupt and Belck refer to in relation to their excavation need to be revisited based on these documents. In their report dating November $30^{\text {th }}$, 1898 , Lehmann-Haupt and Belck mention that they had been excavating for the last two months with up to $80-100$ workers, but in the report ${ }^{47}$ of November $3^{\text {rd }}, 1898$, it is stated that that they will begin excavating the following day and doing so would be against the regulation ${ }^{48}$ and outside the scope of their 1997: 391-400; Çal 2003: 234-270; Eriş 2012: 27-33). 
permit, and therefore they should not be in any way allowed to excavate. The "following day" in the report should refer to November $4^{\text {th }}, 1898$, in which case it would not have been possible for the explorers to excavate during the previous two months.

It is clear from the correspondence the two explorers were closely followed and periodically reported on by the state officials during their work in the region. In the correspondence of 1898 and 1899 , it is specifically noted that they were not allowed to excavate and that the situation should not become a problem. The Ottoman State knew about a small gadget Lehmann-Haupt was carrying on his chest, so it is highly unlikely that it was not aware of an excavation continuing in the midst of Van for almost two months with 80-100 men and had permitted that excavation and the correspondence above fully reveals the situation. Bearing in mind the fact that Belck was injured near Adilcevaz ${ }^{49}$ and that therefore all eyes were on these two explorers make it all the more implausible for them to have been carrying out an excavation at Toprakkale for two months in spite of the various cautions and reports, and therefore the subject remains controversial. Nevertheless, it is still a possibility for them to have performed an illicit excavation through their connections with local people such as Mkrtitsch Maksapetian. ${ }^{50}$ We know from the above correspondence that they had indeed carried out an illicit excavation at Nimrud. ${ }^{51}$ It is understood that Lehmann(-Haupt) and Belck had been in Nimrud and Diyarbekir from the spring of 1899 onwards, therefore it would not have been possible for them to implement an excavation in Toprakkale.

It is clear that Lehmann(-Haupt) and Belck did not excavate at Toprakkale in 1898-1899 with firmans from Istanbul (Sevin 2003: 4). To infer that their excavations, considered as a significant milestone in the Urartian studies, were performed meticulously, and to define them as the first scientific study on the subject would be erroneous. The site has not provided new or rich data on Urartian culture and history (Salvini 2006: 18). Certain other issues call us to reconsider Lehmann and Belck's activities at Toprakkale, such as the fact that they reveal little on the archaeological context (Zimansky 2011: 60-61), they do not publish an architectural plan, and also the discrepancies surrounding the dates they excavated as well as the lack of an excavation permit. Although many other artefacts were published in subsequent years, they did not publish any plans of the site. ${ }^{52}$ The only drawing relevant to Toprakkale is the one where the Van Citadel and its vicinity are depicted (Fig. 12), in which the site is roughly sketched (Lehmann-Haupt 1931: II/2). Barnett finds it peculiar that, like Rassam, Lehmann-Haupt did not publish any plans showing the site or its buildings, and remarks that all the information on Toprakkale relies on a single photograph Rassam published in his book (Rassam 1897: 376; Barnett 1950: 13). Aside from Rassam's plan of the temple, Clayton and Lehmann-Haupt's sketches are far from providing insight into the architectural layout of Toprakkale.

Iosif Abgarovich Orbeli. It is said that Orbeli excavated at Toprakkale in person in 1912 and discovered various items. Only a short report exists on his work (Barnett 1950: 25-26; Barnett 1982: 318). It is most likely, however, that he began his excavation in 1911. He made his permit application for his explorations in Van on May $15^{\text {th }}, 1911 /$ May $2^{\text {nd }}, 1327$ and in a response letter, dated June $1^{\text {st }}$, 1911 / 3 Cemaziyelahir 1329 there are instructions for his work to be facilitated. ${ }^{33}$ The short reports on this excavation note the actual date of the excavation. ${ }^{54}$

${ }^{49}$ DH. MKT. 2122/17, 7 Cemazeyilahir 1316/23 Ekim 1898; DH. MKT. 2134/71, 1 Receb 1316/15 Kasım 1898.

${ }^{50}$ Lehmann-Haupt, in his book on his work at Toprakkale, refers to Mkrtitsch Maksapetian as his excavation supervisor (Lehmann-Haupt 1926: 119; Lehmann-Haupt 1931: 469).

${ }^{51}$ MF. MKT. 447/47, 25 Zilhicce1316/6 Mayı 1899; DH. MKT. 2242/130, 28 Rabiulahir 1317/5 Eylül 1899; DH. MKT. 2197/1, 29 Zilhicce 1316/10 May1s 1899.

${ }^{52}$ Baki Ögün states that the temple was excavated during Lehmann-Haupt's work at Toprakkale in 1898 and that a complete plan was drawn (Öğün 1984: 36); however, the whereabouts of this plan remains unknown.

\footnotetext{
${ }^{53}$ Sent to the Ministry of Interior (Dahiliye Nezareti) from the War Ministry (Harbiye Nazırı) in response to a telegram dated May $15^{\text {th }}, 1911 /$ May $2^{\text {nd }}, 1327$. It states that they were informed by the Russian Embassy of Mr. Orbeli, an assistant teacher at Petersburg University, who wished to make explorations in the province of Van. Following correspondence, the Third Army inspectors sent a telegram approving $\mathrm{Mr}$. Orbeli's visit, and stating that this would not be of an issue with the army, they say that they will facilitate his work.

${ }^{54}$ Farmakovski in Materiali po Arkeologi Rusii, 1912, Vol. 34; Zapiski Vostochnago Otdjlenya Imperatorskago
} 


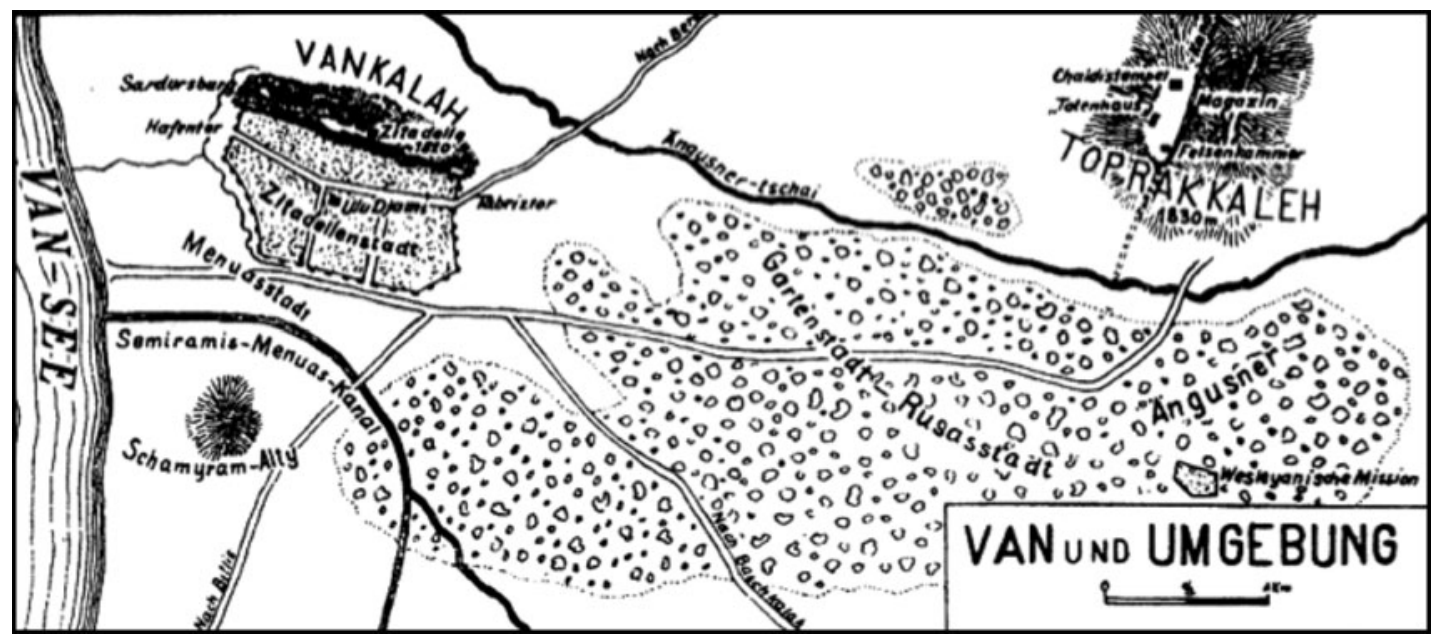

Fig. 12 The sketch of Van Citadel and Toprakkale drawn by Lehmann-Haupt (Lehmann-Haupt 1931: II/2)

Afif Erzen. After a long hiatus, a team led by Erzen began excavating at Toprakkale in 1959 (Erzen 1960: 716-718; Erzen, et al. 1960: 5-22) and continued until 1963 (Erzen 1961: 526-528; Erzen, et al. 1961: 33-35; Erzen 1962: 623-624; Erzen 1963: 541-542; Erzen 1964: 568-572; Erzen 1967: 53-64). Erzen directed a second period of excavations in 1976-77 (Erzen 1977a: 1-59; Erzen 1977b: 58-59; Erzen 1977c: 622-623; Erzen 1978a: 1-15; Erzen 1978b: 539-540; Erzen 1980: 45-58; Erzen 1981: 69-70). By that time, after the excavations of the British and the Germans, there was not much left at the Temple of Haldi, other than several courses of stone (Figs. 13-15).

The early years of the excavation were spent cleaning the rubble and ruins of previous excavations, and surveying the square foundation plan of the Temple of Haldi (13.80mx1380m) (Erzen 1962: 402). As with the temple in Aznavurtepe (Boysal 1961: 200-201), 20×20 cm square pits cut 3-4 cm deep into the bedrock were useful in retrieving the ground plan of the temple. Afif Erzen's work concentrated on the temple, a storage building and related chambers. There is no reference to any fortification or palace building.

Excavated five times within a century, it is the subject of another debate as to how much remains of the citadel of Toprakkale, considered to be the start of Urartian archaeology (Figure 14). Contemporary photographs, foundation pits on the bedrock, and some scattered blocks in particular display this situation (Figures 6-8). The lack of a foundation inscription of the citadel makes it all the more difficult and questionable as to when and by whom it was founded. ${ }^{55}$ Both

Russkago Archeologischeskago Ochschetva, 1911-12, pp. lxxvii-lxxix

${ }^{55}$ Excavations at Toprakkale revealed a shield east of the temple about $4 \mathrm{~m}$ off the eastern foundation (Erzen 1961: 527; Erzen 1967: 62, Resim 20-21). The inscription revealed it was dedicated to Haldi by Rusa, son of Erimena (CTU B 14). Finds on which the names of both Rusa, son of Argišti, and Rusa, son of Erimena are depicted demonstrate that Toprakkale was used by both kings. The name of Rusa, son of Argišti appears on a clay tablet (CTU CT Tk-1) and a plain, undecorated bronze shield (CTU B 12-8). A royal seal impression on a clay bulla (CTU CB Tk-1), linked to Rusa, son of Argišti (Seidl 2012: 177), is about a plough-ox purchased in Arduni. The name of Rusa, son of Erimena, appears on ten bronze shields and fragments (CTU CB 14$1,14-2,14-3,14-4,14-5,14-6,14-7,14-8,14-9,14-11)$. The name of Rusa, on the other hand, appears on one bronze candelabra (CTU B 12-8), a quiver (CTU B 18-4) and a seal impression (CTU Sig. 19-2). These finds, however, do not provide information on the foundation of Toprakkale.
A clue comes from $25 \mathrm{~km}$ east, from the Keşis Lake. A stele discovered by Belck in 1891 (Belck - Lehmann-Haupt 1892: 122-152) refers to a reservoir named "Lake of Rusa", constructed by the Urartian king Rusa, and that by opening canals he brought water to a city called Rusahinili (CTU 14-1; Payne 2006: 285-286). A bulla unearthed in Bastam (CTU CB Ba-6) reads "the year Rusa Argišti(-hi) ascended the throne in Rusahinili before Mountain Qilba(ni)". These two finds were generally taken as evidence for dating Toprakkale to the period of Rusa, son of Argišti. Therefore, it has been suggested that Rusahinili/Toprakkale was founded when Rusai URU.TUR/Bastam was in existence (Salvini 2006: 117). Two stele fragments found in the upper part of the Gövelek village, however, complete the Keşiş Lake stele, the inscriptions (CTU A 14-1) on which prove that Toprakkale was founded by Rusa, son of Erimena, whose name also appears on a second stele with a similar text found in Savacık (CTU A 14-2). This king explicitly states that he was the first king to build a canal here but the issue whether he actually was the king who founded 


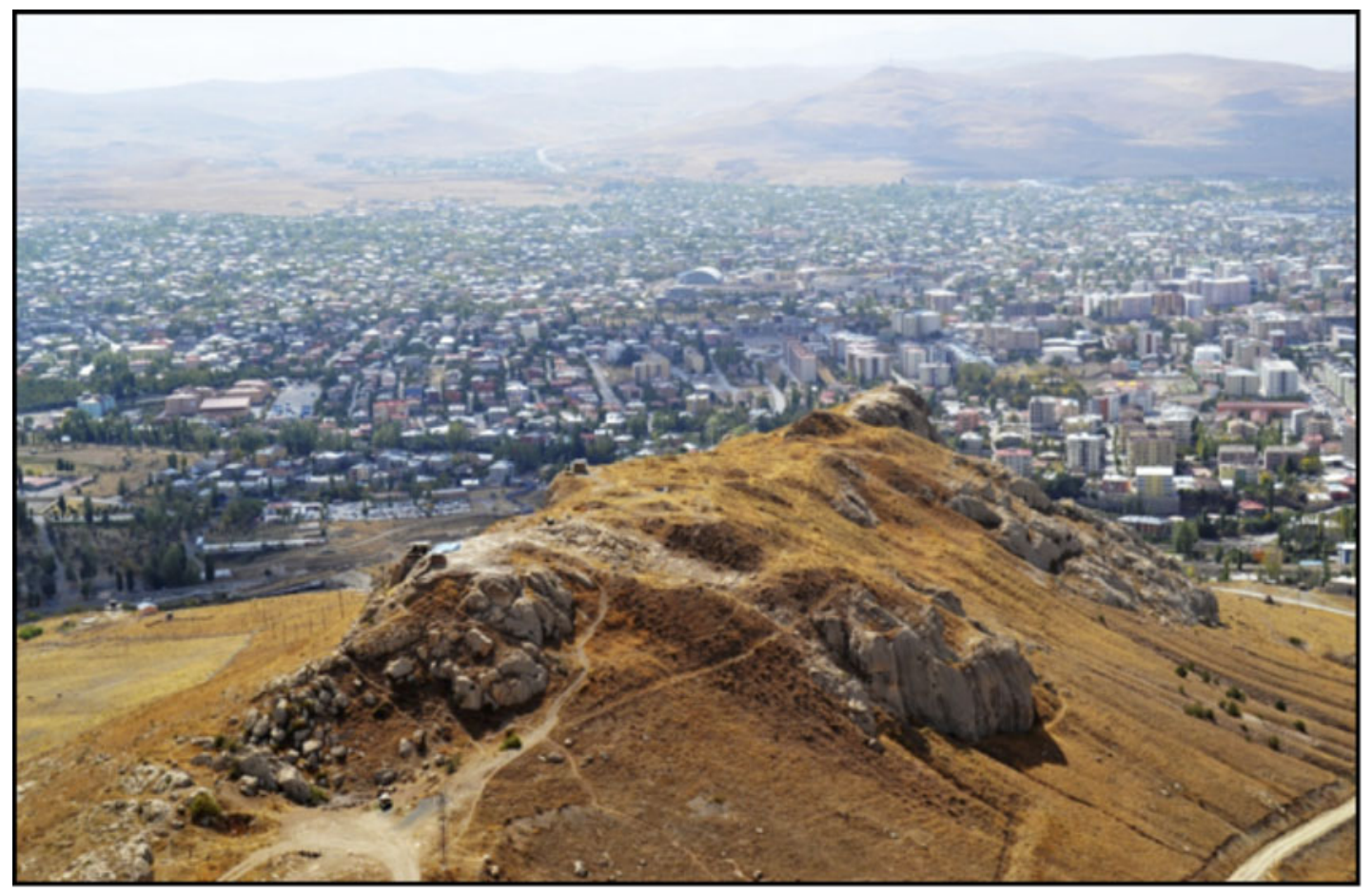

Fig. 13 Toprakkale (K. Işık)

Clayton and Rassam refer to basalt blocks in their descriptions of the temple. Rassam finds it unnecessary to send one to the British Museum, saying they are "bulky" and without any inscriptions (Rassam 1897: 378). Figures 2-4 shows the entrance to the temple and the dispersed stone blocks. The fact that there are no inscribed stones at this location is peculiar when compared with other Urartian temples of other citadels.

\section{Conclusion}

Architectural fragments of Toprakkale, especially the finds collected in legal and illegal excavations carried out in the 1870s in the Haldi temple, can be found in various museum collections across the world. They attracted attention on the antiquities market from early on, resulting in more excavations, which ultimately contributed to the destruction of the site.

The figurines and fragments, considered to belong to a throne in Toprakkale (Srvandztyants 1874: 132-133; Barnett 1950: 43; Merhav 1991: 254-255; Seidl 1994: 67-84; Seidl 1996: 185-186; Seidl 2004: 44) have no parallels in other Urartian period temples. The finds were dispersed to different locations and their context remains unclear. It is hardly likely that these fragments, some obtained through purchase, would belong to a single throne. Not only the excavations of that period are shady but also the supposition that fragments of the same throne were unearthed by different people in a temple that has been excavated numerous times is rather dubious. They can be decorative pieces of other objects obtained or purchased elsewhere. ${ }^{56}$ Uncertainty looms over the

Rusahinili/Toprakkale continues to be discussed (Seidl 2012: 178).

${ }^{56}$ Wartke, who examined the siren in the Berlin Vorderasiatischen Museum, stated that it came to the museum through the London antiquities market and not from Toprakkale (Wartke 1985: 87-100; Salvini 2006: 191). Salvini, on the other hand, states that the siren and bull fragments are quite rare in the Urartu, and writes that the only artefact from a known Urartian archaeological context originates from a rock tomb in Ališar/Verachram/Shotlu on the shores of the Aras River in Iran (Salvini 2006: 191). These artefacts are known to have been found by local villagers in Ališar, and later passed on to the Hermitage Museum in 1859 (Piotrovsky 1967: 37; Piotrovsky 1969: 15, Pl. 103,105,108). The exact location of where they were discovered and their context are controversial. Artefacts that were purchased by various museums and said to have 


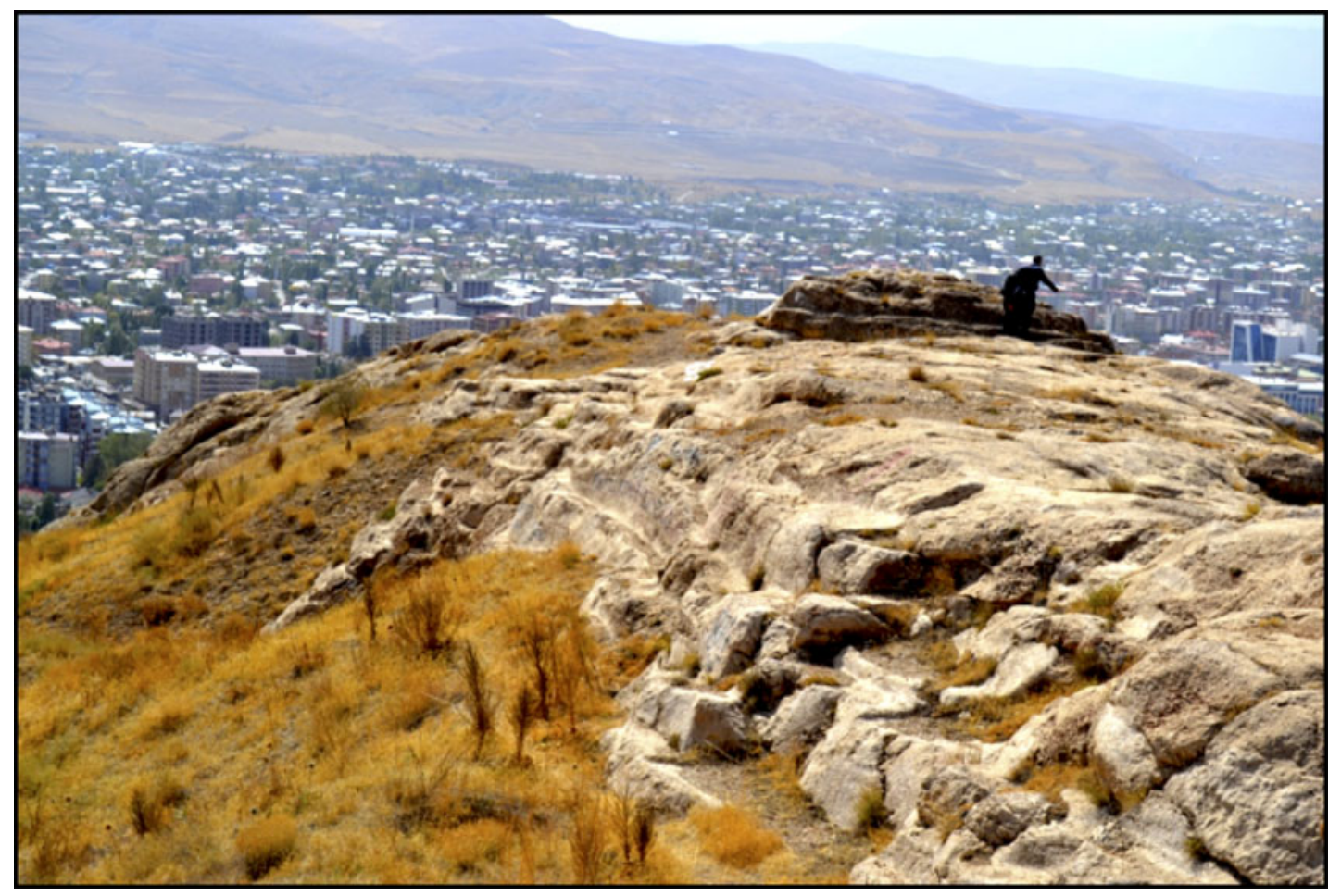

Fig. 14 Toprakkale and foundation beds (K. Iş1k)

exact location of where these furniture fragments were discovered, and they hardly seem to belong to a throne (Çilingiroğlu 2008: 341-346). It is similarly difficult to envisage Toprakkale, ${ }^{57}$ devoid of any inscriptions on the temple (Rassam 1897: 378), as a capital (Burney 1957: 42; Erzen 1967: 53-54; Burney - Lang 1971: 162; Zimansky 2005: 237). In view of the destruction of Mușașir, we should, nevertheless, consider that the Urartian kings may have needed a centre in which to carry out cult rituals and coronation ceremonies much like at the Haldi temple in Mușașir (Sevin 2006: 147; Sevin 2012: 103).

Examination of the excavation periods of Toprakkale reveals conflicting results. The first known excavation in Van is known to have been somewhere other than Toprakkale. Layard, who came to Van in 1849, carried out a short excavation at the Treasure Gate/Analıkı, on the northeastern slope of the Van Citadel (Layard 1853: 398-399) but he does not refer to any finds. We understand from archival documents that Layard knew of "a bronze bull -one-third of the size of the animalwith a human head and a bull's body, one large eagle and two carved snakes" before 1860 and that he somehow got hold of them in the vicinity of Van. Therefore, Rassam's dispatch to Toprakkale by Layard cannot have been solely on the basis of the purchased bronze artefacts, which demonstrate a striking resemblance to the artefacts said to have been discovered in Toprakkale. Layard's relationship with people like Devgants or Srvandztyants, who collected artefacts in Van, paid for illicit excavations and sold the discovered items abroad, should be kept in mind. Hyvernat's desire to purchase a bronze shield from Toprakkale (Müller-Simonis and Hyvernat 1892: 193-194) further demonstrates that Toprakkale served more as a place to obtain artefacts than an archaeological excavation.

The date of Layard's permit (August $16^{\text {th }}, 1880$ ) and the date when Dr Reynolds and Captain Emilius Clayton, the British Vice-Consul, who were charged with digging Toprakkale, began their excavations show a discrepancy. In his letter to Layard dated May $11^{\text {th }}, 1880$, Clayton states that

been found in the second half of the $19^{\text {th }}$ century in places such as Toprakkale and Ališar need to be re-assessed.

\footnotetext{
${ }^{57}$ The temples at Kayalıdere and Altıntepe do not have inscriptions either.
} 


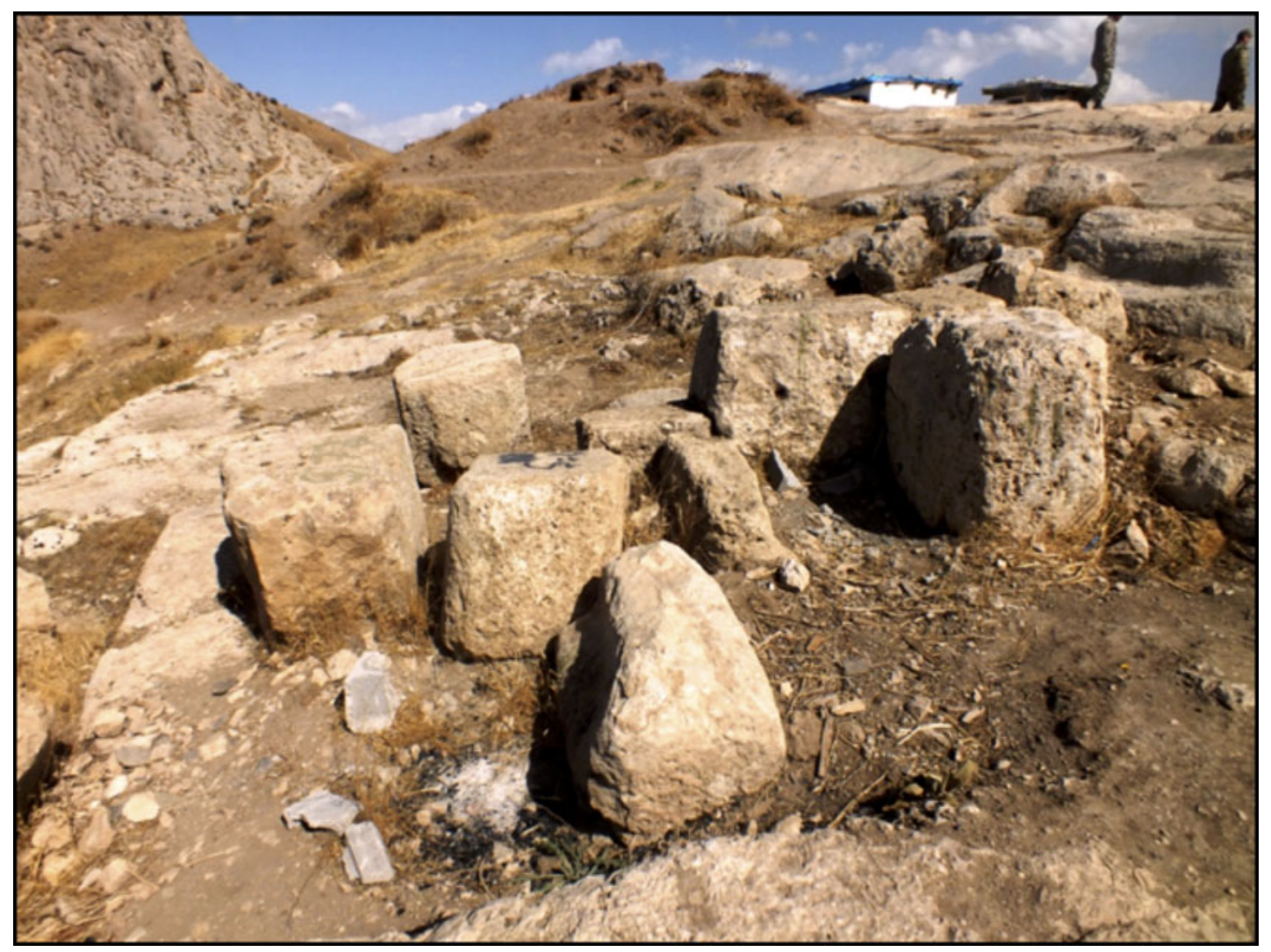

Fig. 15 Stones remaining from the temple area (K. Iş1k)

work began on March $3^{\text {rd }}$, which, in view of the August-dated permit, makes the excavation controversial. The same goes for Lehmann-Haupt and Belck. Reports covering the years 1898 and 1899 (Table 2) establish that their permit was in fact, in today's terminology, a survey permit, and demonstrate that they were allowed to carry out research in Baghdad, Mosul, Van, Mamuretülaziz, Erzurum, Bitlis and Trabzon, but that it was under no condition to be viewed as an excavation permit, and that any violation in that regard would cause problems. It is specifically emphasised that they were not allowed to excavate. It is clear that Lehmann-Haupt and Belck's work in the region had been closely monitored by Ottoman agencies. To think that they excavated close to the centre of Van for two months with about 100 people without the knowledge of the Ottoman State or that the state allowed them to do so is quite improbable. According to the reports of October $23^{\text {rd }}, 1898$ and November $15^{\text {th }} 1898$, the events following Belck's injury near Adilcevaz drew attention to these two researchers. Lehmann-Haupt's various travels in October, including to Keşiş Lake on October 13 ${ }^{\text {th }}, 1898$ (Lehmann-Haupt 1926: 40), Astwadzaschên/ Çavuştepe on October $27^{\text {th }}, 1898$ (Lehmann-Haupt 1926: 60), and further investigations in the same region on October $29^{\text {th }}-30^{\text {th }}, 1898$ (Lehmann-Haupt 1926: 67-69) demonstrate that he was not in Toprakkale during that month. His investigations on the Minua Canal from November $13^{\text {th }}$ onwards also show that he was not present at the site. Lehmann-Haupt continued his surveys during those months. His and Belck's dates do not match one another either. While the report dated November $30^{\text {th }}, 1898^{58}$ states that the team had been excavating at Toprakkale for two months, another report dated November $3^{\text {rd }}, 1898$ gives the next day as the starting day of the excavation. Ottoman documents, on the other hand, emphasise that the situation is a breach of the

\footnotetext{
${ }^{58}$ November $30^{\text {th }}$, 1898 , when Lehmann-Haupt and Belck claim that they had been digging for the last two months in

Toprakkale is the same date as the correspondence of Tahir, the governor of Van, with the Ministry of Interior.
} 
Antiquities Act (1884 Nizamname) and that they should not be allowed to start an excavation under any circumstances. It remains unclear how they could excavate for two months, in spite of these warnings and reports, Belck's injury and Lehmann-Haupt's travels in the region. The entire issue is controversial.

Other reports covering the months of May, July, and September 1899 state that they had been illegally excavating in Nimrud while possessing only a survey permit, and that this permit did not grant them the uncovering and transportation of artefacts. The local authority was instructed to confiscate the items, and keep them safe at the governorship, and to send their photographs. They were also reminded that excavations were subject to permits and that they should not be allowed to remove artefacts or to excavate without obtaining a permit first. Lehmann-Haupt and Belck's work near Mosul in 1899 does significantly prove their absence from Toprakkale during that period. Their investigations in seven provinces and their illicit excavations were immediately reported or prevented. But the presence of people like Devgants, Maksapetian and Kamsarakan, who collected artefacts in the Van region and put them up for sale on the antiquities market is known. As with Layard, Lehmann-Haupt's relationship with them should be considered.

The complexity that began with the excavation periods of Toprakkale, which was dug by Dr Reynolds, Captain Emilius Clayton, Hormuzd Rassam, Iosif Abgarovich Orbeli and Afif Erzen, continues with the controversy over the finds. It is highly likely that the artefacts believed to be unearthed at Toprakkale created a Toprakkale market, which meant that a diverse range of artefacts unearthed elsewhere in the area began to be sold as Toprakkale goods. This site, considered to be where Urartian archaeology began, has only exacerbated issues relating to the period of Rusa, son of Erimena.

\author{
Abbreviations \\ HR. MKT.: Hariciye Nezareti Mektubî Kalemi \\ BEO.: \\ Bab-1 Ali Evrak Odası \\ DH. MKT.: Dahiliye Nezareti Mektubî Kalemi \\ DH. ŞFR.: $\quad$ Dahiliye Nezareti Şifre Kalemi \\ HR. TO.: $\quad$ Hariciye Nezareti Tercüme Odası \\ İ. DH.: $\quad$ İrade Dahiliye \\ İ.HR.: $\quad$ İade Hariciye \\ MF. MKT.: Maarif Nezareti Mektubî Kalemi \\ Y. PRK. UM.: Yildız Perakende Umumi \\ Y. PRK. EŞA.: Y Yıldız Perakende Evrakı Elçilik, Şehbenderlik ve Ataşemiliterlik
}

\title{
Bibliography
}

Barnett, R. D. 1950. "The Excavations of the British Museum at Toprak Kale near Van", Iraq 12 (1): 1-43.

1954. "The Archaeology of Urartu", in Compte Rendu de la troisième Rencontre Assyriologique Internationale organisée à Leiden du 28 juin au 4 juillet 1952 par le Nederlandsch Instituut voor het Nabije Oosten. Leiden: Nederlandsch Instituut voor het Nabije Oosten, pp. 10-18. 1972. "More Addenda from Toprak Kale", Anatolian Studies 22: 163-178.

1982. "Urartu" in J. Boardman, I. E. S. Edwards, N. G. L. Hammond, E. Sollberger (eds.), The Cambridge Ancient History Volume 3, Part 1: The Prehistory of the Balkans, the Middle East and the Aegean World, Tenth to Eighth Centuries BC, Second edition, Cambridge: Cambridge University Press, pp. 314-371.

Belck, W. and Lehmann-Haupt, C. F. 1892. "Ueber neuerlich aufgefundene Keilinschriften in russisch und türkisch Armenien", Zeitschrift für Ethnologie 24: 122-152.

Belck, W. and Lehmann-Haupt, C. F. 1898. "Entdeckungen in Armenien”, Zeitschrift für Ethnologie) 30: 568-591. Belck, W. and Lehmann-Haupt, C. F. 1898. "Armenische Expedition", Zeitschrift für Ethnologie 30: 414-416. Boysal, Y. 1961. "Anzavur'da Definecilerin Meydana Çıkardı̆̆ı Urartu Eserleri”, Belleten 25: 199-212.

Burney, C. A. 1957. "Urartian Fortresses and Towns in the Van Region". Anatolian Studies 7: 37-53.

Burney, C. A. and Lang, D. M. 1971. The Peoples of the Hills. London: Wiedenfeld-Nicolson.

Chantre, E. and Barry, C. 1881. Mission scientifique de Mr Ernest Chantre, sous-directeur du Museum de Lyon, dans la Haute Mésopotamie, le Kurdistan et le Caucase. V. Kurdistan, de Bitlis à Bayazid, Photographies de Mr le Capitaine Barry. France.

Çal, H. 1997. "Osmanlı Devletinde Asar-1 Atika Nizamnameleri”, Vakıflar Dergisi, Ankara 26: 391-400. 
2005. "Osmanlı'dan Cumhuriyete Eski Eser Kanunları" in E. S. Yalçın (ed.), 60. Yılında İlim ve Fikir Adamı Prof. Dr. Kazım Yaşar Kopraman'a Armağan. Ankara: Berikan Yayınları, pp. 234-270.

Çilingiroğlu, A. 2008. "Urartu Tapınakları Kutsal Odalarında Taht Var mıdır (?)" in İ. Delemen, S. ÇokayKepçe, A. Özdizbay, Ö. Turak (eds.), Prof. Dr. Haluk Abbasoğlu’na 65. Yaş Armă̆anı. Euergetes. Festschrift für Prof. Dr. Haluk Abbasoğlu zum 65. Geburtstag. İstanbul: Suna-İnan Kıraç Akdeniz Medeniyetleri Araştırma Enstitüsü, pp. 341-346.

Eriş, M. Ü. 2012. Asar-ı Atika Nizamnamelerinden 2863 Sayılı Kültür ve Tabiat Varlıklarını Koruma Kanununa Mevzuatın Karşılaştırmalı Bir Incelemesi (Unpublished Master Thesis). Ankara: Kültür ve Turizm Bakanlığı Kültür Varlıkları ve Müzeler Genel Müdürlüğü.

Erzen, A. 1960. "Van-Toprakkale kazısı ve bölgede yapılan araştırmalar". Belleten 24 (96): 716-718.

1961. "Toprakkale kazıları”, Belleten 25 (99): 526-528.

1962. "Untersuchungen in der urartäischen Stadt Toprakkale bei Van in den Jahren 1959-1961", Archäologischer Anzeiger 77 (3): 383-414.

1963. "Toprakkale ve Çavuştepe Kazıları", Belleten 27 (107): 541-542.

1964. "Toprakkale, Çavuştepe ve Ünseli (Ernis) Kazıları”, Belleten 28 (111): 568-572.

1967. “1959-1961 Yılları Arasında Toprakkale Araştırmaları”. VI. Türk Tarih Kongresi, Ankara: 20-26

Ekim 1961, Kongreye Sunulan Bildiriler. Ankara: Türk Tarih Kurumu Basımevi, pp. 53-64.

1977a. "Çavuştepe Yukarı Kale ve Toprakkale 1976 Dönemi Kazıları", Anadolu Araştırmaları 4-5: 1-59.

1977b. “Toprakkale, 1976”, Anatolian Studies 27: 58-59.

1977c. "Toprakkale 1976 Çalışmaları”, Belleten 41 (163): 622-623.

1978a. "Çavuştepe Yukarı Kale ve Toprakkale 1977 Çalışmaları", Anadolu Araştırmaları (Jahrbuch fur

Kleinasiatische Forschungen) 6: 1-15.

1978b. “Toprakkale'de 1977 Y1lı Çalışmaları”, Belleten 42 (167): 539-540.

1980. “Toprakkale 1976 Çalışmaları”, Türk Arkeoloji Dergisi 25 (1): 45-58.

1981. “Toprakkale Kazısı 1977 Çalışmaları”, Türk Arkeoloji Dergisi 25 (2): 69-70.

Erzen, A., Bilgiç, E., Boysal, Y., and Öğün, B. 1960. "1959 Van-Toprakkale Sondajları ve Bölgedeki Çalışmalar”, Türk Arkeoloji Dergisi 10 (2): 5-22.

Erzen, A., Bilgiç, E., Boysal, Y., and Öğün, B. 1961. "Van Toprakkale Kazı Heyetinin 1961 Yılı Kısa Çalışma Raporu". Türk Arkeoloji Dergisi 11 (2): 33-35.

Fuchs, A. 2012. "Urartu in der Zeit" in S. Kroll, C. Gruber, U. Hellwag, M. Roaf, and P. Zimansky (eds.), Biainili-Urartu: The Proceedings of the Symposium Held in Munich 12-14 October 2007/ Tagungsbericht des Münchner Symposiums 12.-14. Oktober 2007. Leuven: Peeters, pp. 135-161.

Hellwag, U. 2012. "Der Niedergang Urartus" in S. Kroll, C. Gruber, U. Hellwag, M. Roaf, P. Zimansky (eds.), Biainili-Urartu. The Proceedings of the Symposium Held in Munich 12-14 October 2007/ Tagungsbericht des Münchner Symposiums 12.-14. Oktober 2007. Leuven: Peeters, pp. 227-241.

Kevorkian, R. H. and Paboudjian, P. B. 2012. 1915 Öncesinde Osmanlı Imparatorluğunda Ermeniler. İstanbul: Aras Yayıncilik.

Koçak, A. 2011. The Ottoman Empire and archaeological excavations: Ottoman policy from 1840-1906, foreign archaeologists, and the formation of the Ottoman Museum. İstanbul: Isis Press.

Kroll, S. 2012. "Rusa Erimena in archäologischem Kontext" in S. Kroll, C. Gruber, U. Hellwag, M. Roaf, P. Zimansky (eds.), Biainili-Urartu: The Proceedings of the Symposium Held in Munich 12-14 October 2007 / Tagungsbericht des Münchner Symposiums 12.-14. Oktober 2007. Leuven: Peeters, pp. 183-186.

Layard, A. H. 1853. Discoveries in the Ruins of Nineveh and Babylon; with Travels in Armenia, Kurdistan and the Desert. London and New York: John Murray and G. P. Putnam.

Lehmann-Haupt, C. F. 1901. "Der Tigris-Tunnel", Zeitschrift für Ethnologie 33: 226-244.

1906. Materialien zur älteren Geschichte Armeniens und Mesopotamiens. Berlin: Weidmannsche Buchhandlung.

1926. Armenien Einst und Jetzt II/1. Berlin: B. Behr's Verlag.

1931. Armenien Einst und Jetzt Reisen und Forschungen II/2. Berlin and Leipzig: B. Behrs Verlag/Friedrich Feddersen.

Merhav, R. (ed) 1991. Urartu - A Metal working Center in the First Millennium B.C.E., Jerusalem: Israel Museum.

Müller-Simonis, P. and Hyvernat, H. 1892. Du Caucase au Golfe Persique à travers l'Arménie, le Kurdistan et la Mésopotamie: suivie de notices sur la geographieet l'histoire ancienne de l'Armenie et les inscriptions cuneiformes du bassin de Van. Washington: Université catholique d'Amérique.

Müller, D. H. 1885. "Eine neue Keil-Inschrift von Van”, Oesterreichische Monatsschrift für den Orient 11: 24.

_. 1886. "Neue Van-Inschriften”, Oesterreichische Monatsschrift für den Orient 12 (8): 158.

Öğ̈̈n, B. 1961. "Kurze Geschichte der Ausgrabungen in Van und die türkischen Versuchsgrabungen auf dem Torprak-kale 1959”, Zeitschrift der deutschen Morgenländischen Gesellschaft 111: 254-282.

1984. "Urartulular". Türk Ansiklopedisi 36: 35-75. 
Piotrovsky, B. B. 1967. Urartu: The Kingdom of Van and its Art. Translated by P. S. Gelling. London: Evelyn Adams \& Mackay.

1969. The Ancient Civilization of Urartu. London: Nagel Publishers.

Rassam, H. 1897. Asshur and the Land of Nimrod. Cincinnati: Curts and Jennings.

Reade, J. 1993. "Hormuzd Rassam and His Discoveries", Iraq 55: 39-62.

Reclus, E. 1876. The Earth and Its Inhabitants: The Universal Geography. London: J.S. Virtue \& Co.

Roaf, M. 2012. "Could Rusa son of Erimena have been king of Urartu during Sargon's Eighth Campaign?" in S. Kroll, C. Gruber, U. Hellwag, M. Roaf and P. Zimansky (eds), Biainili-Urartu: The Proceedings of the Symposium Held in Munich 12-14 October 2007 / Tagungsbericht des Münchner Symposiums 12.-14. Oktober 2007. Leuven: Peeters, pp. 187-216.

Salvini, M. 2006. Urartu Tarihi ve Kültürü, (çev. B. Aksoy). Istanbul: Arkeoloji ve Sanat Yayınları.

— 2012. "Das Corpus der urartäischen Inschriften" in S. Kroll, C. Gruber, U. Hellwag, M. Roaf, P. Zimansky (eds.), Biainili-Urartu: The Proceedings of the Symposium Held in Munich 12-14 October 20071 Tagungsbericht des Münchner Symposiums 12.-14. Oktober 2007. Leuven: Peeters, pp. 111-134.

Schachner, A. 2009. Assyriens Könige An Einer Der Quellen Des Tigris. Archaeologische Forschungen im Höhlensystem von Birkleyn und am sogenannten Tigris-Tunnel. Tübingen: Ernst Wastmuth.

Seidl, U. 1994. "Der Thron von Toprakkale. Ein neuer Rekonstruktionsversuch". Archäologische Mitteilungen aus Iran 27: 67-84.

1996. "Urartian Furniture" in G. Herrmann, N. Parker (eds.), The furniture of Western Asia, ancient and traditional: papers of the Conference held at the Institute of Archaeology, University College London June 28 to 30, 1993. Mainz: Philipp von Zabern, pp. 181-186.

2004. Bronzekunst Urartus, Mainz am Rhein: Von Zabern.

2012. "Rusa son of Erimena, Rusa son of Argisti and Rusahinili / Toprakkale" in S. Kroll, C. Gruber, U. Hellwag, M. Roaf, P. Zimansky (eds.), Biainili-Urartu: The Proceedings of the Symposium Held in Munich 12-14 October 2007 / Tagungsbericht des Münchner Symposiums 12.-14. Oktober 2007. Leuven: Peeters, pp. 177-181.

Sekmen, V. 1990. "Van ve Toprakkale'deki Araştırma ve Kazıların Tarihçesi”, Sosyal Bilimler Enstitüsü, Eskiçağ Tarihi Anabilim Dalı (Yayınlanmamış Yüksek Lisans Tezi). Istanbul: İstanbul Üniversitesi.

Sevin, V. 2003. “Lehmann-Haupt’tan Afif Erzen'e Urartu Araştırmaları, Tarih ve Arkeoloji”, Arkeoloji ve Sanat 114: 3-10.

_ 2006. "A Comment on the so-called Urartian Capital City of Toprak Kale", Aramazdl Armenian Journal of Near Eastern Studies 1: 143-149.

2012. Van Kalesi: Urartu Kral Mezarları ve Alttntepe Halk Mezarlı̆̆g. Istanbul: Ege Yayınları.

Srvandztyants, G. V. 1874. Groc'u broc'ew Sasunc 'i Davit'kam Mheri dur. Constantinople.

Tarhan, M. T. 2011. "Baskent Tuspa / The Capital City Tushpa" in K. Köroğlu, E. Konyar (eds.), Urartu Doğu'da Değissim / Transformation in the East. İstanbul: Yapı Kredi Yayınları, pp. 286-333.

Wartke, R. B. 1985. "Die Berliner Kesselattasche VA 2988”, Altorientalische Forschungen 12 (1): 87-100.

1990. Toprakkale. Untersuchungen zu den Metallobjekten im Vorderasiatischen Museum zu Berlin. Berlin: Akademie-Verlag.

Zimansky, P. 2005. "The Cities of Rusa II and the End of Urartu", in A. Çilingiroğlu and G. Darbyshire (eds.), Anatolian Iron Ages V. Proceedings of the Fifth Anatolian Iron Ages Colloquium held at Van, 6-10 August 2001. London: British Institute of Archaeology at Ankara, pp. 235-240.

2011. "Unutulan ve Tekrar Hayata Dönen Bir Krallık: Urartu Çalş̧maları ve Literatürü/A Kingdom Revived from Oblivion: Urartian Studies and Literature" in K. Köroğlu and E. Konyar (eds.), Urartu: Do ğu'da Değişim / Transformation in the East. İstanbul: Yapı Kredi Yayınları, pp. 54-69.

\author{
Bülent Genç \\ Mardin Artuklu University \\ Faculty of Letters \\ Department of Archaeology \\ Artuklu-Mardin \\ Turkey \\ bulendgenc@hotmail.com
}




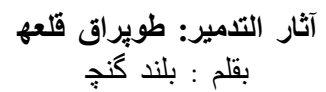

نبذة مختصرة

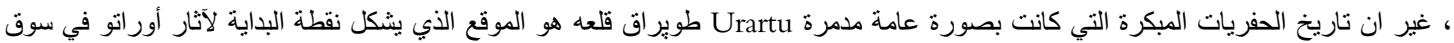

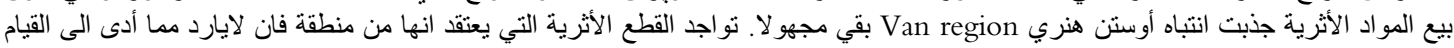

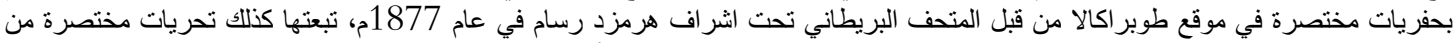



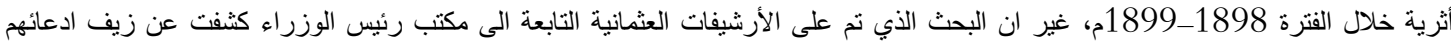

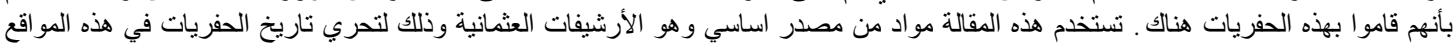

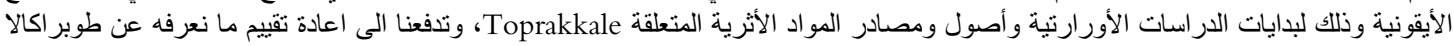

